\title{
By How Much Does GDP Rise If the Government Buys More Output?
}

\begin{abstract}
During World War II and the Korean War, real GDP grew by about half the increase in government purchases. With allowance for other factors holding back GDP growth during those wars, the multiplier linking government purchases to GDP may be in the range of 0.7 to 1.0 , a range generally supported by research based on vector autoregressions that control for other determinants, but higher values are not ruled out. New Keynesian macroeconomic models yield multipliers in that range as well. Neoclassical models produce much lower multipliers, because they predict that consumption falls when government purchases rise. Models that deliver higher multipliers feature a decline in the markup ratio of price over cost when output rises, and an elastic response of employment to increased demand. These characteristics are complementary to another Keynesian feature, the linkage of consumption to current income. The GDP multiplier is higher-perhaps around 1.7-when the nominal interest rate is at its lower bound of zero.
\end{abstract}

ajor contractions in economic activity bring policies of temporary expansion in government purchases of goods and services. The severe contraction that hit the U.S. and world economies in 2008 was no exception. The need for fiscal expansion was particularly acute because monetary policy had driven nominal short-term safe interest rates down to zero without heading off the contraction. Fiscal policy, including increases in federal purchases and in state and local purchases financed by federal grants, was an important part of the government's response to a severe recession.

A major issue for fiscal policy is how much total output increases when the government temporarily buys more goods and services. The ratio of the output increase to the purchases increase is the government purchases multiplier. I emphasize that my concern in this paper is with government purchases, not all of government spending, which includes transfers and interest payments as well as purchases. I assume in all cases that the products 
the government purchases enter preferences in a separable fashion: they do not affect households' marginal rate of substitution between consumption and work or between consumption this year and in any future year. Military spending is the obvious example. If instead the government provided consumers with goods and services they would have purchased anyway, the resulting multiplier would be lower. In the extreme case, where the government purchases consumption goods and provides them to consumers, the multiplier would be zero in the standard life-cycle model.

I exclude effects that operate through externalities. One such effect arises from the fact that the government, as the nation's agent for collective action, may have uses for output that exceed the private value of the output. For example, law enforcement is underprovided by private action and may be underprovided by current government action. If the increase in government purchases includes more spending on law enforcement, its value may exceed its direct contribution to GDP. I leave out that increased value, which could be attributed either to the purchases or to the increase in GDP that occurs because more enforcement makes other production more efficient. Another example is road building, where the benefits accrue mainly in the future, because roads are part of the public capital stock. I omit benefits related to externalities not because I think they are unimportant, but because I want to focus on a limited, strictly macroeconomic question. Thus, as a general matter, I do not offer a welfare analysis of government purchases, but rather one important piece of a welfare analysis, having to do with the aggregate effects, mainly in the labor market, of the government's increase in product demand.

I assume that no special distortionary taxes apply during the brief period of the countercyclical purchases; the government balances its budget in the long run with whatever taxes it normally uses. I also do not comment on the other major branch of fiscal stimulus, tax reductions. An analysis of fiscal stimulus in the form of higher transfers or lower taxes would make use of the conclusion about the effects of higher purchases on overall economic activity, because it is a fair presumption that the effects of higher consumer purchases are similar to the effects of higher government purchases. But I do consider the effects of the subsequent financing of increased government purchases, both explicitly in the models I study and implicitly in my empirical work, which assumes that the public knows that the government must eventually service the debt it has issued to pay for its higher purchases. Here my focus on temporary increases in purchases is critical: permanent increases have a different effect because households will respond by cutting consumption in anticipation of permanent increases in taxes, a 
wealth effect. I demonstrate the irrelevance of any wealth effect for temporary programs of higher government purchases.

The paper describes a closed economy. In effect, it is about the world economy, although I use U.S. data to find parameter values. In the context of the events of 2008 and 2009, a global focus is appropriate, because every major economy has suffered substantial declines in employment and output, and many have responded with increases in government purchases.

I start with a discussion of the direct evidence from simple regressions about both the output multiplier and the analogous consumption multiplier for government purchases. Given the reasonable assumption that movements in military purchases are exogenous and the fact that they account for much of the variation in government purchases, the natural approach is to study the econometric relationship between output and consumption, on the one hand, and military spending, on the other. The resulting multipliers are about 0.5 for output and slightly negative for consumption. Although the standard errors of these estimates are agreeably small, the estimates are under suspicion for understating the multipliers, because the bulk of the evidence comes from the command economy of World War II and may not be relevant to today's market economy. Omitting World War II from the sample yields similar multipliers with rather larger standard errors, based largely on the Korean War buildup, but these too are questionable because that buildup was accompanied by large increases in tax rates. Changes in military purchases from the Vietnam War period, the Reagan years, or the two wars in Iraq are not large enough to deliver usable estimates of the multipliers. I conclude that the evidence from U.S. historical experience on the magnitude of the multipliers only makes the case that the multiplier is above 0.5 .

I next report evidence from vector autoregressions (VARs), which find fairly consistently that the output multiplier is in the range from 0.5 to 1.0 and that the consumption multiplier is somewhat positive. To varying extents, these estimates include adjustments for factors such as taxes that may correct downward biases in the simple regressions.

The paper then turns to models, specifically those derived from the blending of neoclassical and Keynesian theory that has flourished in the past decade under the name New Keynesian economics. Following many earlier authors, I demonstrate that the purely neoclassical general-equilibrium model without unemployment yields the pretty much unshakable conclusion that increases in government purchases come largely out of investment and consumption and do not raise output substantially. The output multiplier is well under 1 , and the consumption multiplier is quite negative. The 
reason is that increased output in this type of model can come only from increased employment. Without a reservoir of unemployed workers to draw down, any increase in labor input must drive the wage down, resulting in less labor supply. The neoclassical model thus predicts small increases in output and fairly large declines in consumption.

A key idea of modern macroeconomics that results in more reasonable multipliers is that the margin of price over cost falls during expansions; that is, the markup ratio declines as output rises. Often this property is expressed as stickiness of the price level: prices stay constant during a boom that raises input costs. Other rationalizations based on oligopoly theory or other principles deliver the result directly. The declining markup permits the wage to rise, or at least not fall as much as it would with constant markup during an expansion. Hence, it permits the household to supply much more labor when the government increases its claim on output.

A second key idea of modern macroeconomics needed to rationalize a reasonably positive output multiplier is elastic labor supply. Research based on household data is adamant that the elasticity of labor supply is below 1 even after adjustment for the income effect. Such an elasticity precludes a substantially positive output multiplier with any reasonable response of the markup to changes in output. It takes both a declining markup and elastic labor supply to generate a substantial output multiplier.

My approach to rationalizing a high wage elasticity of labor supply starts from the observation that most of the cyclical movement in work effort takes the form of variations in unemployment. I raise the elasticity of labor supply to incorporate the response of unemployment to changes in labor demand, following a search-and-matching approach to the labor market. A standard dynamic general-equilibrium model with a sufficiently responsive markup and realistically elastic effective labor supply (including the response of unemployment) yields an output multiplier as high as just below 1, in accord with the direct evidence.

One might think that the traditional Keynesian hypothesis of rigid wages would be a close cousin of elastic labor supply, but this thought turns out to be quite wrong. An unresponsive wage constrains the immediate effect of an increase in government purchases to zero, because employment and thus output are determined entirely by the equality of the marginal product of labor and the wage. This predetermination of output remains in an economy where the markup ratio declines with higher output.

The standard model with responsive markup and elastic labor supply still generates a negative consumption multiplier. I show that adding com- 
plementarity between hours worked and consumption-a topic of extensive recent research-can tame the negative multiplier. The logic is that employed people consume significantly more market goods and services than do the unemployed, who have more time to create nonmarket equivalents. My preferred specification for matching the observed positive multiplier for output and the slightly negative multiplier for consumption has a substantial negative response of the markup of price over cost to changes in output, a fairly elastic response of employment to changes in labor demand, and a degree of complementarity of consumption and work estimated from micro data.

Modern models generally embody the life-cycle model of consumption, where households use credit markets to smooth consumption. It is widely believed that replacing this feature of models with a traditional consumption function linking consumer spending to current income will boost the output and consumption multipliers. The issue then becomes by how much an increase in government purchases crowds out investment. Traditional Keynesian models assume rigid real wages, in which case output is determined on the demand side of the labor market by firms equating the marginal product of labor to the fixed real wage. With output unresponsive, crowding out is complete and the output multiplier is zero. Adding partial borrowing constraints to an otherwise standard New Keynesian model does boost the consumption multiplier.

Multipliers are not structural constants. They describe the responses of endogenous variables to changes in the driving force of government purchases. Multipliers depend on monetary policy. In normal times, monetary policy leans against the expansionary effect of increased government spending, reducing the multipliers. But when monetary policy lowers nominal interest rates to their minimum value of zero, the offsetting effect disappears, and so an economy at the lower bound has higher multipliers. In an economy with an output multiplier for government purchases of just under 1 in normal times, the multiplier rises to 1.7 when monetary policy becomes passive with a zero nominal interest rate.

I conclude that the efficacy of stimulus from higher government purchases depends on two features of the economy: a markup of price over cost that declines as output expands, and a substantially wage-elastic labor supply or the equivalent. Both features are related to traditional Keynesian views about price and wage stickiness: the negative response of the markup can be viewed as price stickiness, and elastic labor supply as wage stickiness. Both features appear to describe the U.S. economy, although research on this topic is still far from definitive. 
I review the evidence on the movement of the markup ratio as output expands. The hypothesis of a negative response implies that the share of profit in total income should fall during expansions. In fact, that share rises. The most promising rationalization involves a substantial amount of wage smoothing. Then the observed increase in profit during booms is the combination of two phenomena: an increase associated with wage contracts that give management the bulk of the benefit of higher revenue, partly offset by a decline in profit per unit of output. But this is pure guessworkI lack any handle on measuring wage smoothing. There is no meaningful factual support for the key hypothesis that the markup ratio declines with output.

I show that the expansion of government purchases so far enacted to deal with the severe current recession is too small to add meaningfully to our knowledge on this subject—or to offset much of the loss in output. A debate about whether the government purchases multiplier is 1.0 or 1.5 is completely off the point in this respect.

\section{Regression Estimates of Output and Consumption Multipliers}

I begin by estimating the government purchases multipliers for output and consumption in simple (ordinary least squares) regressions and in VARs.

\section{I.A. Estimates from Simple Regressions on Military Purchases}

The most direct way to measure the government purchases multipliers is to exploit large and arguably exogenous fluctuations in military spending. I start with a review of that evidence for the United States over the past 80 years, using the following specification:

$$
\frac{z_{t}-z_{t-1}}{y_{t-1}}=m_{z} \frac{g_{t}-g_{t-1}}{y_{t-1}}+\varepsilon_{t} \text {. }
$$

Here $z$ is either $y$ for the output multiplier $m_{y}$ or $c$ for the consumption multiplier $m_{c}$. The equation also contains a constant (not shown). Note that using the same denominator on the left and the right preserves the normal definition of the multiplier as the dollar change in output or consumption per dollar of increased government purchases.

In this approach I am treating the change in nonmilitary government purchases as one of the sources of the noise $\varepsilon_{t}$. Because these purchases grow smoothly, their difference has little variability. The alternative of using 
military spending as an instrument for total purchases gives essentially identical results.

I assume that the change in military spending $g$ is uncorrelated with the non- $g$ component of the right-hand-side variable $\varepsilon_{t}$. This identifying assumption has two aspects. First, military spending does not respond to forces determining GDP or consumption, such as monetary or financial forces, but only to geopolitical events. I have long believed that this aspect of the identifying assumption is among the more plausible in macroeconomics. Second, no other determinants of output or consumption growth change when government purchases change. The basis for this aspect of the identifying assumption is much weaker. In particular, when military spending rises substantially, two other policy responses may occur: command-type interventions in the economy, including rationing, and increases in taxes. Both of these presumably decrease consumption demand and thus reduce output growth. The result is a failure of the identifying assumption in the direction of a negative correlation between the disturbance $\varepsilon_{t}$ and military spending, and thus a downward bias in the estimate of the multiplier $m_{z}$. I conclude that the value of the multiplier is probably better interpreted as a lower bound than as an unbiased estimate.

Because the movements in GDP and consumption induced by changes in government purchases have essentially the same dynamics as the changes in purchases, it is not necessary (in fact, it is inefficient) to find the innovation in $g$ and then track the response to the innovation, as would occur in a VAR. The advantage of a VAR is that it can account for other influences, notably taxes, and isolate the causal effect of government purchases. The simple regression considered here confounds the effects of wartime increases in purchases with the effects of accompanying tax increases. Temporary increases in purchases for stimulus purposes are not accompanied by comparable tax increases. I discuss evidence from VARs in the next subsection.

To form the differences in the data, I use the various versions of National Income and Product Accounts table 1.1.6, Real Gross Domestic Product, Chained Dollars. Each version of the table uses a different base year for the deflator. For the overlap years, I take the average of the two measures of the two changes; these are usually identical to two digits. I use this approach because the deflator for military spending drifts relative to the GDP deflator, and I wish to retain the usual interpretation of the multiplier as the effect of one current dollar of purchases on GDP or consumption, also measured in current dollars. 
Table 1. Ordinary Least Squares Estimates of Government Purchases Multipliers for Military Spending ${ }^{a}$

\begin{tabular}{lcc}
\hline Period & GDP multiplier & Consumption multiplier \\
\hline $1930-2008$ & 0.55 & -0.05 \\
& $(0.08)$ & $(0.03)$ \\
$1948-2008$ & 0.47 & -0.12 \\
& $(0.28)$ & $(0.10)$ \\
$1960-2008$ & 0.13 & -0.09 \\
& $(0.65)$ & $(0.29)$ \\
$1939-48$ & 0.53 & -0.05 \\
& $(0.07)$ & $0.02)$ \\
$1949-55$ & 0.48 & -0.18 \\
& $(0.56)$ & $0.05)$ \\
$1939-44$ & 0.36 & -0.11 \\
& $(0.10)$ & $(0.03)$ \\
$1945-49$ & 0.39 & -0.04 \\
& $(0.08)$ & $(0.05)$ \\
\hline
\end{tabular}

Source: Author's calculations.

a. Numbers in parentheses are standard errors.

Table 1 shows the results of the regressions for output and consumption. The top row shows that, over the entire sample 1930 through 2008, the output multiplier is just over half, with a standard error of 0.08 , and the consumption multiplier is close to zero, although slightly negative, with a standard error of 0.03 . The higher precision of the consumption multiplier estimate arises because the change in consumption has a much lower volatility than does the change in real GDP.

As I noted earlier, estimates of the multiplier that include the huge changes in military spending during World War II are biased downward because important parts of the economy were run on command principles during the war. Direct controls on consumption through rationing arguably held back consumption growth that would have occurred under free-market conditions. Other factors, including the draft and the wartime surge in patriotism, result in an upward bias. Although I am inclined to believe that the net bias is downward, there is no solid evidence one way or the other.

The other rows in table 1 show the evidence from various subperiods. The second row starts the sample in 1948, after the rise and fall of wartime military purchases. The multiplier estimates are similar to those for the whole period but with much larger standard errors. The confidence interval for the output multiplier runs from about zero to about 1 . The confidence interval for the consumption multiplier remains fairly tightly concentrated near zero. 
The third row of the table starts the sample in 1960, several years after the Korean War. It shows that military spending did not move enough during the Vietnam War, the Reagan buildup, or the two wars in Iraq to allow precise estimation. The estimates are fully consistent with those in the first two rows but are almost completely uninformative about the output multiplier. They do, however, rule out larger positive or negative values of the consumption multiplier.

The fourth row reinforces the message of the earlier rows by showing that the results for just the period enclosing the World War II expansion and contraction of military spending are virtually identical to those for the whole period. Essentially all the identifying power comes from the large movements during World War II.

The fifth row looks at the years enclosing the Korean War. The estimates are similar to those found for the periods including World War II but have much larger standard errors, especially for the output multiplier.

The last two rows of table 1 break World War II into its expansion phase, ending in 1944, and a phase containing the military contraction and the resumption of normal economic conditions, from 1945 to 1949. One of the strengths of the parsimonious specification I use is its ability to deliver useful results with a small number of observations. The results are interesting because many economists - most recently, Lawrence Christiano, Martin Eichenbaum, and Sergio Rebelo (2009)—believe that the multipliers are higher when the economy is slack. The U.S. economy was extremely slack in 1939, the first year of the expansion phase in the table. The results here give no support to the view of higher multipliers in a slack economy. The downward multipliers found for the period from 1945 to 1949 are virtually identical to those for the expansion from slack starting in 1939. Both are measured with good precision.

Robert Barro and Charles Redlick (2009) consider similar evidence in a regression framework that includes tax rates and other determinants of GDP along with government purchases. They use data starting in 1917 and so take advantage of World War I, another period when the military component of purchases rose dramatically. Their estimates of the output multiplier range from 0.59 to 0.77 ; the estimate for all data starting in 1917 is 0.64 , with a standard error of 0.10 . Their estimates of the consumption multiplier are close to zero. They do not report results without the tax variables, but it appears that their inclusion somewhat increases the estimates. Thus, tax increases with negative effects tend to coincide with increases in government purchases. 
The most important lesson from the data on military purchases is that all the real information comes from big wars. The standard errors in table 1 reflect this fact, rising sharply when the big wars are omitted. Another way to see the point is to observe that the regression coefficient is

$$
\begin{aligned}
m_{z} & =\frac{\sum_{t} \Delta z_{t} \Delta g_{t}}{\sum_{\tau}\left(\Delta g_{\tau}\right)^{2}} \\
& =\frac{\sum_{t} \frac{\Delta z_{t}}{\Delta g_{t}}\left(\Delta g_{t}\right)^{2}}{\sum_{\tau}\left(\Delta g_{\tau}\right)^{2}} \\
& =\sum_{t} W_{t} \frac{\Delta z_{t}}{\Delta g_{t}} .
\end{aligned}
$$

Here $\Delta z_{t}$ is the change in real GDP or consumption as a fraction of initial real GDP less its mean, and $\Delta g_{t}$ is the change in military purchases as a fraction of GDP less its mean. Thus, the overall estimate of the multiplier is a weighted average of year-to-year observed multipliers, where the weights $W_{t}$ depend on the square of the growth in military purchases.

Figure 1 shows these weights calculated from the data on military purchases and real GDP. The only visibly positive weights are for the two wars. Of the two, World War II is vastly more informative. There is little hope of learning much about the multipliers from any data after the mid-1950s. Note that the weights are the same for the output and the consumption multipliers.

I conclude that the regression evidence from big wars demonstrates that the government purchases multiplier is probably at least 0.5 , based on the hypothesis that the net effect of biases is downward. World War II does not yield a higher estimate of the multiplier than does the Korean War, despite the fact that the buildup starting in 1940 was from a much more slack economy than the one starting in 1950. Possible explanations for the failure to find the expected relationship between initial slack and the multiplier include more aggressive command interventions in the earlier mobilization and the fact that World War II involved enormous expansions in motor vehicles, ships, and aircraft, all highly specialized industries subject to bottlenecks.

\section{I.B. Estimates from Vector Autoregressions}

VARs are a more powerful approach to measuring multipliers, in principle. The simple regressions in the previous section take all the movements 
Figure 1. Annual Weights Implicit in OLS Estimates of Output and Consumption Multipliers ${ }^{\mathrm{a}}$

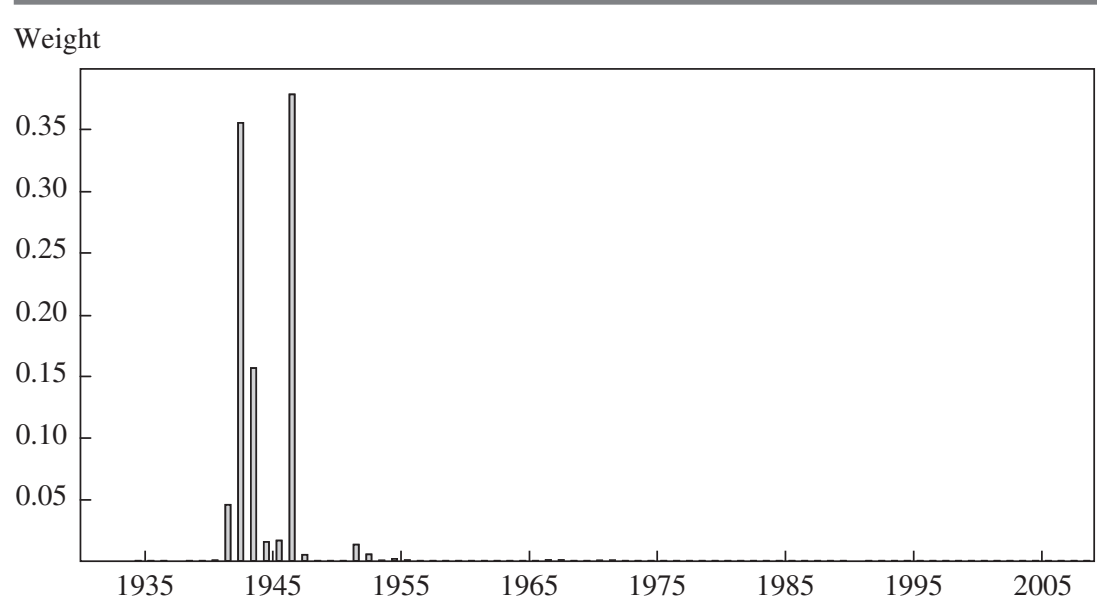

Source: Authorís calculations.

a. Each weight derives from the square of military spending in that year.

in real GDP and consumption not attributable to changes in government purchases as noise, captured by the residual. Even if these movements arise from driving forces that are uncorrelated with military purchases, so that the estimated multipliers are unbiased, the estimates have a high sampling error. A VAR can soak up much of the noise by associating it with other causal factors, thus generating more precise estimates than a simple regression. Further, a VAR can take account of effects that are correlated with changes in government purchases that result in biases in the simple regressions. Probably the main effect of this type is that from the tax rate, although this correlation can be captured in a simple regression as in Barro and Redlick (2009). By far the biggest increase in government purchases over the sample included in the VARs reported below occurred during the Korean War, when tax rates also increased substantially.

Olivier Blanchard and Roberto Perotti (2002), Jordi Galí, David LópezSalido, and Javier Vallés (2007), Perotti (2008), Andrew Mountford and Harald Uhlig (2008), and Valerie Ramey (2009) estimate VARs subject to a variety of identification schemes, all of which basically rely on the exogeneity of movements of government purchases. Blanchard and Perotti consider two versions of their VAR, one with a deterministic trend and the other with a stochastic trend. Ramey estimates elasticities rather than multipliers; I convert these to multipliers by dividing by the ratios of 
Table 2. Literature Estimates of Government Purchases Multipliers from Vector Autoregressions ${ }^{\mathrm{a}}$

\begin{tabular}{|c|c|c|c|c|}
\hline \multirow[b]{2}{*}{ Source } & \multirow[b]{2}{*}{$\begin{array}{c}\text { Type of } \\
\text { multiplier }\end{array}$} & \multicolumn{3}{|c|}{ Estimate } \\
\hline & & $\begin{array}{c}\text { On } \\
\text { impact }\end{array}$ & $\begin{array}{c}\text { After } \\
4 \text { quarters }\end{array}$ & $\begin{array}{c}\text { After } \\
8 \text { quarters }\end{array}$ \\
\hline Blanchard and Perotti (2002, table 4) & Output & $\begin{array}{c}0.90 \\
(0.30)\end{array}$ & $\begin{array}{c}0.55 \\
(0.80)\end{array}$ & $\begin{array}{c}0.65 \\
(1.20)\end{array}$ \\
\hline \multirow[t]{2}{*}{$\begin{array}{l}\text { Galí, López-Salido, and Vallés } \\
\text { (2007, table 1) }\end{array}$} & Output & $\begin{array}{c}0.41 \\
(0.16)\end{array}$ & $\begin{array}{c}0.31 \\
(0.34)\end{array}$ & $\begin{array}{l}0.68 \\
(0.45)\end{array}$ \\
\hline & Consumption & $\begin{array}{c}0.07 \\
(0.10)\end{array}$ & $\begin{array}{c}0.11 \\
(0.19)\end{array}$ & $\begin{array}{c}0.49 \\
(0.28)\end{array}$ \\
\hline \multirow[t]{2}{*}{ Perotti (2008, figure 3) } & Output & $\begin{array}{c}0.70 \\
(0.20)\end{array}$ & $\begin{array}{c}1.00 \\
(0.50)\end{array}$ & $\begin{array}{l}1.20 \\
(0.50)\end{array}$ \\
\hline & Consumption & $\begin{array}{c}0.10 \\
(0.05)\end{array}$ & $\begin{array}{c}0.30 \\
(0.20)\end{array}$ & $\begin{array}{c}0.40 \\
(0.25)\end{array}$ \\
\hline Mountford and Uhlig (2008, table 4) & Output & $\begin{array}{c}0.65 \\
(0.39)\end{array}$ & $\begin{array}{c}0.27 \\
(0.78)\end{array}$ & $\begin{array}{l}-0.74 \\
(1.95)\end{array}$ \\
\hline Ramey (2008, figure 10a) & Output $^{\mathrm{b}}$ & $\begin{array}{c}0.30 \\
(0.10)\end{array}$ & $\begin{array}{c}0.50 \\
(0.25)\end{array}$ & $\begin{array}{c}0.90 \\
(0.35)\end{array}$ \\
\hline Ramey (2008, figure 10b) & Consumption $^{c}$ & 0.02 & -0.17 & -0.09 \\
\hline
\end{tabular}

Source: Literature cited.

a. Numbers in parentheses are standard errors.

b. Ramey (2008) states results for both output and consumption as elasticities, which here have been converted to multipliers.

c. Separate elasticities were estimated for durables, nondurables, and services, so standard errors for total consumption are unavailable.

government purchases to GDP and to consumption of nondurables and services. Ramey's innovation is to identify shocks to government purchases from events presaging rises in military spending, which she weights by the present value of the predicted increase in military purchases.

Table 2 shows the estimated multipliers for real GDP and in some cases consumption for the above five studies at three points in time after an innovation in government purchases: on impact, after four quarters, and after eight quarters. None of the estimated output multipliers is as high as 1 at impact. The impact multipliers range from 0.3 to 0.9 . The variation arises from differences in identification strategies. Perotti, and Galí and his coauthors, find consumption multipliers as high as 0.49 , whereas Ramey's estimates are only slightly positive or negative. The difference again arises from her identification strategy rather than the other authors' use of the innovation in all government purchases. The standard errors in table 2 indicate the wide range of uncertainty in the responses, especially at longer lags. Note that all of these studies use the same data, so that their estimated coefficients are highly correlated with each other. The standard 
errors are indicative of the overall uncertainty from VARs; they would not be smaller for an average across the various estimates.

One important difference between these earlier VAR estimates and the question pursued in this paper is that government purchases rose very persistently in response to innovations over the period from 1948 to the present. The Korean War was the exception to the general rule that military spending is transitory: it remained high after the end of that war because of the intensification of the Cold War. By contrast, the increase in government purchases to offset a recession is intended to be transitory.

\section{I.C. Conclusions on the OLS and VAR Estimates}

Empirical work using simple regressions or more elaborate VARs finds output multipliers in the range from 0.5 to 1.0 , with a few exceptions, and consumption multipliers in the range from somewhat negative to 0.5 . All of this work is limited in its ability to measure multipliers for the period from 1948 onward by the lack of variation in government purchases, especially in its most exogenous component, military purchases. Figure 1 showed that essentially all the information comes from World War II and the Korean War. Both the simple regressions and the VARs infer the multipliers entirely or mainly from the rise in military spending starting in 1940 (for the simple regressions only) and again in 1950, and the VARs are probably only partly successful in adjusting for taxes and other confounding forces. Thus, one cannot say that the evidence rules out multipliers above 1.0. In the rest of the paper, I will speak as if the evidence clearly supports an output multiplier a bit below 1 and a consumption multiplier a bit negative. To avoid painful repetition, I will not comment each time on the weakness of the evidence on this point.

\section{Multipliers Derived from Structural Macroeconomic Models}

Today, most research-oriented macroeconomic models combine, in varying proportions, ideas from dynamic optimization. In the majority of these models, households choose consumption to balance present against future satisfaction, according to the life-cycle-permanent-income principle, although some households may face binding borrowing constraints. In almost all models, firms choose inputs so as to maximize firm value, subject to the wage for labor and the rental price for capital. In many models, firms are price-setting monopolists facing fairly but not fully elastic demand. A popular assumption is that a firm keeps price constant for an extended 
period of random length, after which the price pops to its value-maximizing level. Few modern macroeconomic models embody any monetary sector. Rather, consistent with modern central bank practice, the economy has a Taylor rule relating the interest rate to the rate of inflation. Finally, models view households as having preferences that govern labor supply, but they may permit a varying gap between labor demand and labor supply, on the view that the wage is sticky in the shorter run but clears the labor market in the longer run.

I omit consideration of macroeconomic models used in proprietary forecasting. I do not have access to information about the underlying economic principles of those models. In particular, I do not comment on the analysis by Christina Romer and Jared Bernstein, which uses an average of multipliers from "a leading private forecasting firm" and the Federal Reserve's FRB/US model (Romer and Bernstein 2009, p. 12). I do find that their fairly high estimate of the output multiplier is in line with the findings of a model applied to the conditions of 2009 with the federal funds rate at its lower bound of zero.

The class of models favored by academic macroeconomists and many central banks has a neoclassical growth model at its core. With prices adjusted frequently to firm value-maximizing levels and wages adjusted frequently to market-clearing levels, the economy grows reasonably smoothly along a full-employment path, with some volatility associated with changing rates of productivity growth, changing levels of market power, changing preferences, and other driving forces. A topic of intense debate is how much of the observed volatility of output and employment would occur without price and wage stickiness.

Two recent developments in general-equilibrium macroeconomics are worth noting. First is the development of coherent theories of unemployment, which are replacing oversimplified ideas that unemployment is just the gap between labor supply and labor demand. Second is the recognition that the models are missing truly important features of financial markets, especially the widening of spreads that occurs in a financial crisis and recession between the interest rates that private sector borrowers pay and the safe government rate.

My discussion of models and their implications for the output multiplier for government purchases adheres to the general philosophy of the class of models sketched above. I begin with the neoclassical growth model core. A single equation from that model - the first-order condition for balancing consumption of goods and services against work effort-has played a huge role in the literature on government purchases multipliers over the 
past 30 years. When that equation is given its full role, as in a simple neoclassical model, the consumption multiplier for government purchases is quite negative. Much of the history of commentary on government purchases multipliers looks for alterations in the model that boost the consumption multiplier toward or even above zero, in accord with the empirical studies that do not generally find very negative values.

The consumption-work trade-off is irrelevant in a sticky-wage model, because workers can be off the labor supply function implied by the firstorder condition. But an otherwise neoclassical model with a sticky wage cannot have much of an output multiplier, and it cannot have a nonnegative consumption multiplier, as I will show.

\section{II.A. The Neoclassical Starting Point}

Suppose people have preferences described by the within-period utility function

$$
\frac{c^{1-1 / \sigma}}{1-1 / \sigma}-\gamma \frac{h^{1+1 / \psi}}{1+1 / \psi}
$$

Here $\sigma$ describes the curvature of utility with respect to consumption of goods and services, $c$; it is the intertemporal elasticity of substitution and the reciprocal of the coefficient of relative risk aversion. The parameter $\psi$ describes the curvature of utility with respect to the volume of work, $h$, and is the Frisch elasticity of labor supply. Finally, the parameter $\gamma$ controls the overall disamenity of work.

With the price of goods and services normalized at 1 and a real wage of $w$, the first-order condition for the optimal mix of consumption and work is

$$
w c^{-1 / \sigma}=\gamma h^{1 / \psi} .
$$

Under what conditions will an increase in government purchases (or any other source of higher employment and output) actually raise work effort $h$ ? If work effort does rise, the real wage must fall, given that the capital stock is a state variable whose level cannot change immediately. For $h$ to rise, the left-hand side of the equation must rise, despite the fall in the real wage. The only way for the product to fall is for $c^{-1 / \sigma}$ to rise by a higher proportion than the wage falls. This rise requires, in turn, that consumption fall.

Much of the history of formal macroeconomics of the past three decades rests on this issue. In this model any driving force that raises product demand and thus employment and output must depress consumption, 
contrary to the evidence and common sense. The real business cycle model broke the conundrum by invoking a stimulus that raised wages: it took bursts of productivity growth to be the driving force of employment fluctuations, rather than the changes in product demand that had generally been the primary driving force in earlier models. But the real business cycle model implies that an increase in government purchases achieves an increase in hours of work and output by depressing consumption through wealth and intertemporal substitution effects. The model is fundamentally inconsistent with increasing or constant consumption when government purchases rise.

Parameter values that alleviate but do not avoid the property of consumption declines with higher government purchases are low values of intertemporal substitution, $\sigma$, and high values of the elasticity of labor supply, $\psi$. Advocates of the real business cycle model have adopted the second enthusiastically but have been less keen on low $\sigma$, because $\sigma=1$ (log of consumption) is needed to match the absence of a trend in hours of work as real wages have risen. Another helpful feature of preferences is to introduce complementarity of consumption and hours, but again this cannot deliver an increase in consumption along with an increase in hours of work. I discuss complementarity in section II.D.

To see how the basic marginal-rate-of-substitution condition limits the multiplier, consider the simplest static general-equilibrium model. The technology is Cobb-Douglas:

$$
y=h^{\alpha} .
$$

Capital is fixed and normalized at 1 . The real wage is the marginal product of labor:

$$
w=\alpha h^{-(1-\alpha)} .
$$

Output is divided between consumption and government purchases $g$ :

$$
y=c+g
$$

Combining the first-order condition from equation 4 and the two previous equations, I get a single equation to describe general equilibrium:

$$
(y-g)^{-1 / \sigma}=\frac{\gamma}{\alpha} y^{\frac{1+1 / \psi}{\alpha}-1}
$$


It is convenient to normalize the model, without loss of generality, so that output is 1 at a designated level of government purchases $g$. This implies

$$
\gamma=\alpha(1-g)^{-1 / \sigma}
$$

Then the output multiplier is

$$
m_{y}=\frac{\mathrm{d} y}{\mathrm{~d} g}=\frac{\alpha}{\alpha+\sigma(1-g)(1-\alpha+1 / \psi)} .
$$

Because $\alpha \leq 1$ and $\psi>0$, the conclusion follows, under the assumptions adopted so far, that the output multiplier cannot exceed 1 . Further, the output multiplier is an increasing function of the labor supply elasticity $\psi$, an increasing function of the labor elasticity of production $\alpha$, and a decreasing function of the consumption curvature parameter $\sigma$. Conditions under which the output multiplier is close to 1 are the following: highly elastic labor supply (large $\psi$ ) and low diminishing returns to labor ( $\alpha$ close to 1$)$; high curvature of utility in consumption ( $\sigma$ close to zero); or government purchases close to all of output ( $g$ close to 1 ).

Because all output is either consumed or purchased by the government, the consumption multiplier is simply the output multiplier less 1 . Thus, under the assumptions I have made so far, the consumption multiplier is never positive.

Note that the expansion in output that occurs in this economy with an increase in government purchases $g$ results in a lower wage: employers would not be willing to increase employment and lower the marginal product of labor if the cost of labor did not decline. The parameter $\psi$ controls the response of labor supply to the lower wage. A higher value of $\psi$ results in a larger decline in hours from the decrease in the wage, in the substitution sense (again, $\psi$ is exactly the Frisch wage elasticity of labor supply). The reason that a higher value of $\psi$ results in a larger increase in hours when $g$ increases is the income effect, which also depends on $\psi$. The consumption curvature parameter $\sigma$ also enters the income effect. For parameters that bring the multiplier close to 1 , the income effect is swamping the substitution effect. Notice as well that the labor elasticity $\alpha$ enters the output multiplier because it controls the wage depression accompanying the increase in output. With $\alpha$ close to 1 , diminishing returns are weak and the substitution effect is correspondingly smaller, so there is less offset to the income effect. 
The elasticity of the production function with respect to the labor input, $\alpha$, is widely believed to be around 0.7 . The critical (and controversial) parameter in the model is $\psi$. Empirical work with household data suggests that $\psi$ lies in the range from 0.2 to 1.0 (see the papers cited in the appendix to Hall 2009). With $\sigma$ at the fairly standard value of 0.5 and $g$ at 0.2 , the output multiplier is about 0.4 , at the low end of the range of empirical findings, and the consumption multiplier is -0.6 , out of line with all of the empirical evidence.

I will now consider a set of modifications of the model that improve its match to the evidence. These incorporate, in turn, variations in the markup of price over cost, unemployment, complementarity of consumption and hours of work, and a negative response of investment to changes in government purchases. The last modification requires moving to a dynamic model.

\section{II.B. Endogenous Markup of Price over Cost}

The neoclassical model assumes competition in output and labor markets. The New Keynesian branch of macroeconomics drops that assumption in favor of market power in product markets and makes the extent of market power depend on the state of the economy. Forces, such as higher government purchases, that expand output also make the economy more competitive, with a lower markup of price over cost.

New Keynesian and many other macroeconomic models take the product price as sticky. In a monetary economy, this hypothesis can take the form of a sticky nominal price level combined with variations in factor prices. My approach is to continue to normalize the price of output at 1 , so that the implication of price stickiness is that factor prices are inside the competitive factor-price frontier. Firms have market power. That power is high in slumps and low in booms; hence, markups are countercyclical. The relationship between price stickiness and countercyclical markups has been noted by many authors, notably Julio Rotemberg and Michael Woodford (1992).

Sticky-price models generally derive the variable markup from the Calvo pricing model and Spence-Dixit-Stiglitz preferences, but I will take it for now as a primitive feature of the economy. I build this feature into the earlier model with a constant-elasticity relationship between the markup and output: $\mu(y)=y^{-\omega}$. I continue to normalize the reference level of output, the point where I take the derivative for the multiplier, at 1 . Now the wage equals the marginal revenue product of labor,

$$
w=\frac{1}{y^{-\omega}} \alpha h^{-(1-\alpha)} .
$$


The output multiplier becomes

$$
m_{y}=\frac{\mathrm{d} y}{\mathrm{~d} g}=\frac{\alpha}{\alpha+\sigma(1-g)[1-(1+\omega) \alpha+1 / \psi]} .
$$

The more responsive the markup to changes in output (the higher $\omega$ ), the higher the output multiplier. Further, the output multiplier can now exceed 1, and thus the consumption multiplier can be positive. The condition for an output multiplier above 1 is

$$
\omega>\frac{1-\alpha+1 / \psi}{\alpha} .
$$

If $\psi=0.5$, the markup elasticity $\omega$ needed to deliver an output multiplier of 1 is 3.3 , far above the plausible range. With $\omega=0.5$, the output multiplier is 0.5 and the consumption multiplier is -0.5 .

\section{II.C. Unemployment and the Employment Function}

Even today, many general-equilibrium models struggle to explain the volatility of employment without explicit consideration of unemployment. But good progress has occurred in this area. Monika Merz (1995) and David Andolfatto (1996) introduced unemployment as described by Dale Mortensen and Christopher Pissarides (1994) into otherwise neoclassical models. Blanchard and Galí (2007) did the same for the New Keynesian model. With a Nash wage bargain, the wage is sufficiently flexible that fluctuations in driving forces of reasonable volatility cause almost no movement in unemployment, as Robert Shimer (2005) showed in an influential paper. Blanchard and Galí introduced sticky, non-Nash wages to generate realistic unemployment volatility. Hall (2009) developed a more general framework based on a broad family of bargaining solutions and with standard preferences to replace the linear preferences in Mortensen-Pissarides.

That framework describes an employment function $n(w, \lambda)$ that gives the fraction of the labor force employed (1 minus the unemployment rate). Here $w$ is the wage in the sense of the marginal product of labor; the actual compensation paid to workers may differ because of two-part pricing and wage smoothing. $\lambda$ is the marginal utility of consumption. Its inclusion as an argument arises because of the diminishing marginal rate of substitution between consumption and work. A second function, $h(w, \lambda)$, is the Frisch supply function for hours of work per employed worker (not to be 
confused with hours per person, the variable considered in models that disregard unemployment). I assume that an efficient relationship between worker and employer results in the setting of hours on the basis of the marginal product of labor, and I show that this assumption results in a reasonable account of the movements of hours per employed worker. For the purposes of studying a transitory alteration in the economy such as countercyclical government purchases, $\lambda$ can be taken to be roughly constant, so the functions become $n(w)$ and $h(w)$. Further, the size of the labor force does not change significantly in response to the forces causing the business cycle, so I can standardize it at 1 and write the total volume of work effort as $n(w) h(w)$. This object replaces the labor supply function in a general-equilibrium model.

I take the Frisch elasticity of hours per employed worker-the elasticity of $h(w)$ - to be 0.7 , based on research surveyed in the appendix to Hall (2009). This elasticity is a cousin of the compensated elasticity of labor supply and must be nonnegative according to the standard theory of household behavior. This elasticity is far below the level needed to explain the observed volatility of total hours of work per person.

The employment function $n(w)$ is not the result of household choice. Rather, as in the Mortensen-Pissarides model, it is determined by the interaction of jobseekers and employers in the labor market. If the marginal product of labor rises and compensation paid to workers does not rise as much (compensation is sticky), then employers put more resources into recruiting workers, the labor market tightens, and unemployment falls. Thus, with sticky compensation, $n(w)$ is an increasing function of the marginal product of labor, $w$. The stickier compensation, the higher the elasticity. I find that the elasticity is 1.2 (Hall 2009, table 1, p. 300). Compensation is quite sticky: under a Nash bargain, the elasticity would be only barely positive.

The elasticity of work effort $n(w) h(w)$ is, accordingly, 1.9. The conclusion of this analysis is that the use of a standard labor supply specification with a fairly high elasticity, namely, 1.9, properly captures both the lower elasticity of the choice of hours by employed workers and the elasticity resulting from sticky compensation in a search-and-matching setup following Mortensen and Pissarides. For almost 30 years, a chorus of criticism (including, I confess, my voice) fell upon Finn Kydland and Edward Prescott (1982) and the proponents of general-equilibrium models with elastic labor supply. Now it turns out that their specification fits neatly into the Mortensen-Pissarides framework, with Nash bargaining replaced by some other type of bargaining that results in a sticky level of compensation. 
With the Frisch wage elasticity $\psi$ raised to 1.9 , the output multiplier becomes 0.8 and the consumption multiplier -0.2 , an important step toward realism.

\section{II.D. Consumption-Work Complementarity}

Although the empirical finding of a somewhat negative consumption multiplier is hardly new (see Hall 1986), the model considered here so far yields consumption multipliers that are rather more negative than those estimated in empirical studies. One further ingredient, consumption-work complementarity, helps to close the gap. Florin Bilbiie (2009) shows that complementarity cannot turn the consumption multiplier positive in models that lack a negative response of the markup to increases in output, but it can bring the multiplier close to zero. Christiano, Eichenbaum, and Rebelo (2009) discuss the role of complementarity in connection with variable markups and cite a number of earlier treatments of this subject for preferences that assume a particular pattern of complementarity.

In the Frisch framework, as laid out in Hall (2009), complementarity means that goods and services consumption rises when the wage rises, with marginal utility held constant. Equivalently, it means that the marginal utility of consumption rises when an individual moves from nonwork to work or when the individual works more hours. I have not found any studies of the cross effect in a Frisch system or in other representation of preferences. But the dependence of consumption on work levels, with wealth or marginal utility held constant, has been the subject of an extensive recent literature. Mark Aguiar and Erik Hurst (2005) provide a well-known study of the subject. The "retirement consumption puzzle"the drop in consumption of goods and services upon cessation of workis resolved nicely by complementarity. A retired person relies more on home production and less on purchases in the market, given the availability of time previously devoted to work. The same point applies to changes in consumption during a spell of unemployment, with the possibly important difference that retirement is more likely to be a planned, expected event than is unemployment. Some of the decline in consumption observed among the unemployed may be the result of imperfect insurance markets and lack of liquid savings.

Hall and Paul Milgrom (2008) set out a family of preferences with complementarity:

$$
\frac{c^{1-1 / \sigma}}{1-1 / \sigma}-\chi c^{1-1 / \sigma} h^{1+1 / \psi}-\gamma \frac{h^{1+1 / \psi}}{1+1 / \psi}
$$


Positive values of the parameter $\chi$ introduce an increase in the marginal utility of consumption $c$ that depends on hours of work $h$ (provided, as I assume, $\sigma<1$ ). I use the following parameter values: $\sigma=0.4, \psi=1.54$, $\chi=0.334$, and $\gamma=1.1$. The Frisch elasticities for these parameter values are

-own-price elasticity of consumption: -0.5

-wage elasticity of hours of work: 1.9

- elasticity of consumption with respect to the wage: 0.4 .

See the appendix to Hall (2009) for a discussion of the household-level evidence on the own-price elasticity of consumption and the cross elasticity. In the latter case, the evidence relates to the decline in consumption that occurs at retirement or upon unemployment. Hall and Milgrom show how to calculate the cross elasticity to match the consumption decline.

With the negative of the elasticity of the markup, $\omega$, at 0.5 , the output multiplier is 0.97 and the consumption multiplier is -0.03 , figures easily consistent with the empirical evidence.

\section{Dynamic Modeling}

The output multiplier is relatively high in the static model because of the income effect. In a dynamic version of the model, the analogue of the income effect is the wealth effect: when people feel poorer because of current and future government purchases, they work harder. When the program of purchases is transitory, as I assume throughout this paper, the wealth effect can be much smaller than the corresponding static income effect. Put differently, the wealth effect would be comparable to the static income effect if the increase in purchases were permanent, but if the increase is transitory, people will smooth their work effort and consumption. They accomplish the smoothing by investing less. The economy thus pays for temporary government purchases in part by cutting investment rather than by increasing output, so the output multiplier is smaller.

To incorporate the investment effect, one needs a dynamic model that characterizes the investment process. I will use James Tobin's now-standard approach, based on the distinction between installed capital and newly produced investment goods. The price of installed capital is $q$ in units of investment goods, which I take to be the same as consumption goods, in a one-sector model. The flow of investment equates the marginal benefit of investment, the price $q$, to the marginal installation and acquisition cost, which I take to be linear in the flow of investment as a fraction of the earlier capital stock: 


$$
q_{t}=\kappa \frac{k_{t}-k_{t-1}}{k_{t-1}}+1
$$

The parameter $\kappa$ measures the capital adjustment cost: if $\kappa=0, q$ is always 1 and there are no adjustment costs. If $\kappa$ is large, most fluctuations in the demand for capital are absorbed by the price of installed capital, $q$, rather than causing changes in the amount of installed capital. In that case the decline in investment when government purchases increase will be small, and the earlier analysis of a static economy will yield a fairly accurate estimate of the output and consumption multipliers.

Capital rents for the price

$$
b_{t}=q_{t-1}\left(r_{t}+\delta\right)-\Delta q_{t} .
$$

The interest rate $r_{t}$ is the net marginal product of capital; $\delta$ is depreciation. Capital demand in period $t$ equals capital supply as determined in the previous period:

$$
(1-\alpha) \frac{y_{t}}{\mu b_{t}}=k_{t-1} \text {. }
$$

At the beginning of a period, the stock of installed capital is $k_{t-1}$; people choose hours of work $h_{t}$. At the end of the period, output $y_{t}$ becomes available and is allocated to government purchases $g_{t}$, consumption $c_{t}$, and investment, including adjustment cost, resulting in the new capital stock, $k_{t}$. The law of motion for capital is

$$
k_{t}+\frac{\kappa}{2} \frac{\left(k_{t}-k_{t-1}\right)^{2}}{k_{t-1}}=(1-\delta) k_{t-1}+y_{t}-c_{t}-g_{t} \text {. }
$$

I continue to consider only a real model and to embody sticky prices in the form that matters for my purposes, the countercyclical markup that a sticky product price implies.

Worker-consumers order their paths of hours and goods consumption according to the utility function in equation 14 . The first-order condition for the optimal mix of consumption and work is

$$
w c^{-1 / \sigma}\left[1-\chi(1-1 / \sigma) h^{1+1 / \psi}\right]=h^{1 / \psi}\left[-\chi(1+1 / \psi) c^{1-1 / \sigma}-\gamma\right] .
$$


The economy's discounter is

$$
m_{t, t+1}=\beta \frac{c_{t+1}^{-1 / \sigma}}{c_{t}^{-1 / \sigma}} \frac{1-\chi(1-1 / \sigma) h_{t+1}^{1+1 / \psi}}{1-\chi(1-1 / \sigma) h_{t}^{1+1 / \psi}} .
$$

The Euler equation for consumption is

$$
\left(1+r_{t+1}\right) m_{t, t+1}=1
$$

Following a government purchases shock, purchases decline from an initial level $g+\bar{g}$ with a rate of persistence of $\phi$ :

$$
g_{t}=\bar{g}+g \phi^{t}
$$

Capital at the end of period $T$ is required to be at the economy's stationary level: $k_{T}=k^{*}$. For reasonably large $T$, the result is very close to the infinite-horizon solution. I use the value $k_{0}=k^{*}$ for the initial capital stock before the government purchases shock. I use the solution to the nonstochastic perfect-foresight model as a (close) approximation to the impulse response of a stochastic model to an innovation in government purchases in an AR(1) equation with persistence $\phi$. I take $T=80$ quarters, but the model has the turnpike property that makes $T$ essentially irrelevant to the results as long as it is more than a decade. I take the parameter $\kappa$ that controls capital adjustment cost to be 8 at a quarterly rate, corresponding to 2 at an annual rate, a representative value from the literature on this subject.

Table 3 gives parameter values for the base case and for a number of variants, to illustrate the roles of the various features added to the original neoclassical model. I picked the value of the markup response parameter, $\omega=0.7$, to yield a reasonable value of the output multiplier. All the other parameters are drawn as described earlier from my review of earlier research.

For the cases described in table 3 , table 4 shows some of the properties of the dynamic model in terms of impulse response functions, comparable to those shown earlier for the structural VAR results. The first pair of columns, labeled "On impact," reports the multipliers, defined as the immediate effects of one dollar of increased government purchases on output or consumption, in dollars of real GDP. In the base case the multipliers are 0.98 for output and -0.03 for consumption. After four quarters the output effect becomes smaller, 0.68 , and the consumption effect remains essentially the 


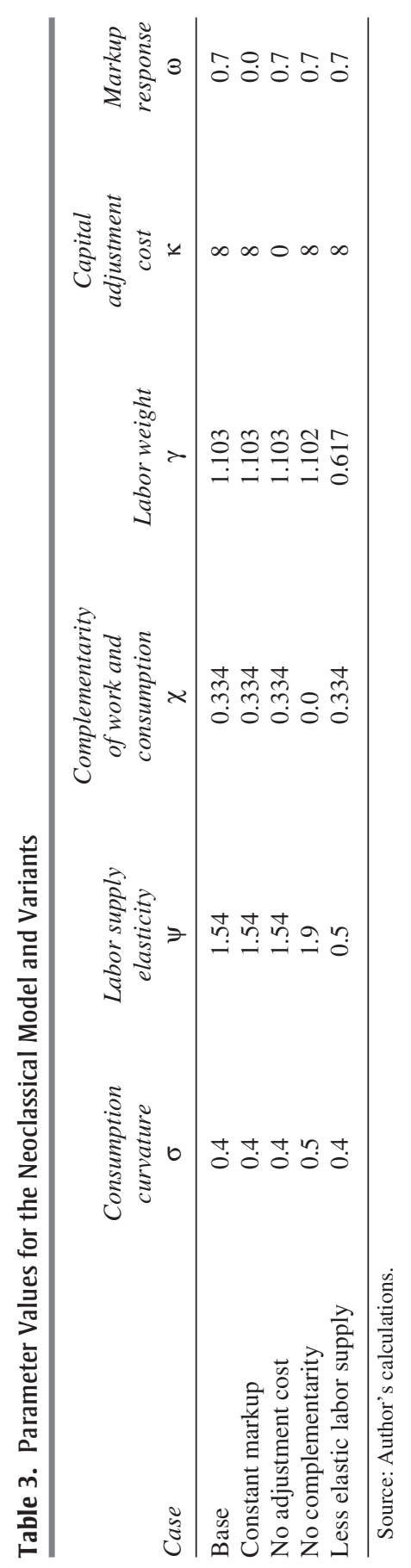




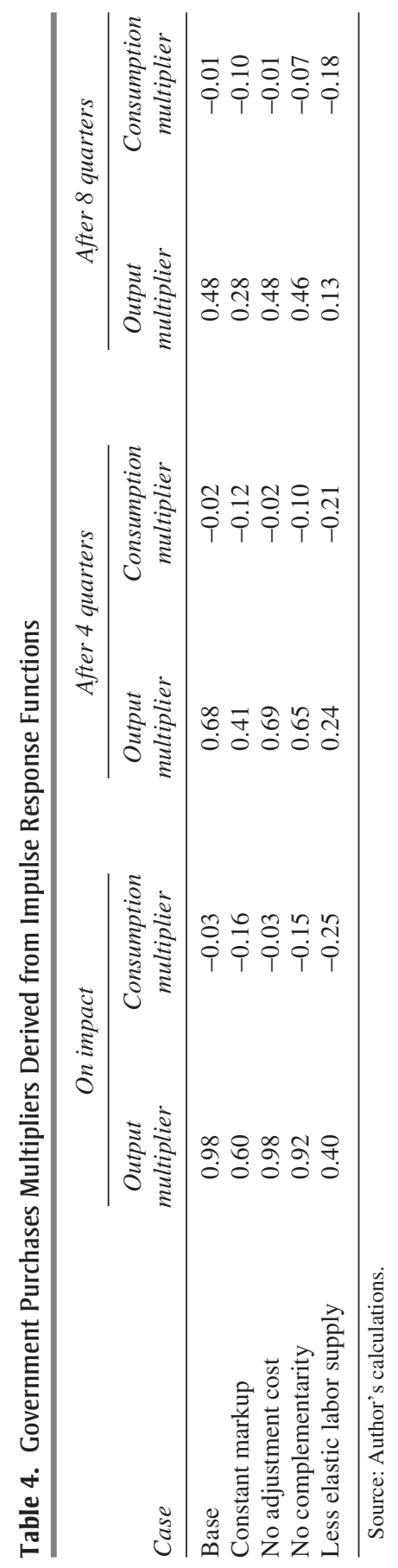


same, at -0.02 ; after eight quarters they shrink even further. Recall that the increase in government purchases declines at a 30 percent annual rate, so that much of the change in the response is the direct result of the decline in the stimulus from the extra purchases.

Eliminating the New Keynesian property of a markup ratio that declines with output and replacing it with a constant markup of zero (that is, dropping $\omega$ from 0.7 to 0 ; second row of table 4) alters the responses dramatically. The impact multipliers become 0.60 for output and -0.16 for consumption, both of which are small relative to the earlier evidence. Again, these become even smaller as the impulse dies out over four and eight quarters.

On the other hand, removing adjustment costs for capital formation (third row of table 4) has essentially no effect. The reason is simple. If the output multiplier is about 1 and the consumption multiplier is zero, the effect of government purchases on investment must be about zero (here the closed-economy assumption is important). To put it differently, one effect of the government purchases is to drive up the real interest rate and inhibit investment. The second effect is the accelerator: investment increases because businesses add capacity to serve the demand for more output. In the base case the two effects offset each other. Because nothing happens to investment when government purchases increase, adjustment costs are irrelevant to their effect on other variables.

The fourth row of table 4 shows that dropping the complementarity of work and consumption has a small downward effect on the output response and a larger downward effect on the consumption response, pushing it into unrealistic territory. Thus, complementarity - a feature of household production and preferences well supported by recent research-helps to make the model's properties fit the data.

The bottom row of the table shows the overwhelming importance of elastic labor supply (including the large part of the elasticity arising from unemployment) in bringing the model into agreement with the data. With less elastic labor supply, all the other features of the model, including the price stickiness that accounts for the variable markup, leave its output response at about a third of the realistic value and its consumption response deeply negative. Although I favor modeling the elastic response with a labor supply function, the New Keynesian literature (not to mention its Keynesian predecessors) speaks of the same response as wage stickiness. Some of this distinction is only one of vocabulary, but I will show later that a sticky wage does not result in as realistic a model as does elastic labor supply. 


\section{Other Issues}

In this section I address three issues: whether estimates of the government purchases multiplier are affected by such factors as the frequency of price adjustment and the response of the central bank; how the estimates change when nominal interest rates are near their zero lower bound; and whether they change noticeably when the model includes a wealth effect.

\section{IV.A. Is an Analysis without Consideration of the Price Level Appropriate?}

In most modern macroeconomic models, including all of those to be discussed in section VII, the central bank intervenes in the economy to stabilize the price level or the rate of inflation. Consequently, the bank's policy rule is part of the model, and the government purchases multipliers depend on this rule. The more draconian the response to inflation, the lower the multipliers. The analysis in this paper does not ignore this point but puts it in the background: the central bank's policy rule is one of the determinants of the elasticity $\omega$ of the markup of price over cost.

To explore the relationship between the standard New Keynesian model and the reduced-form approach taken in this paper, based on the negative response of the markup ratio to output, I created a version of the New Keynesian model embodying all the same features and parameters as the benchmark model just discussed, altered to include the Calvo (1983) sticky-price specification with a parameter $\theta$, the quarterly probability that a price remains fixed, and an elasticity of demand $\epsilon=5$ facing each producer whose price is sticky. The model also includes a standard Taylor rule governing the path of the price level in relation to the interest rate. The online appendix to this paper gives a full description and code for the model. ${ }^{1}$

In the New Keynesian model, the stickiness of prices is the fundamental source of variation in the markup of price over cost: such variations occur when firms are hit by demand surprises that raise marginal cost during the time when the price is fixed. Marginal cost rises because firms move up their short-run marginal cost functions, and because the wage rises. Many New Keynesian models invoke sticky wages as well as sticky prices, but I continue to rely on a high wage elasticity to explain larger movements in employment in the face of small changes in wages.

1. Online appendices for all papers in this issue may be found on the Brookings Papers webpage (www.brookings.edu/economics/bpea) under "Conferences and Papers." 
Table 5. Price Persistence, Multipliers, and Markup Elasticities in a New Keynesian Model

\begin{tabular}{lccc}
\hline $\begin{array}{l}\text { Price } \\
\text { persistence }^{\text {a }} \theta\end{array}$ & $\begin{array}{c}\text { Output } \\
\text { multiplier }\end{array}$ & $\begin{array}{c}\text { Consumption } \\
\text { multiplier }\end{array}$ & $\begin{array}{c}\text { Elasticity of the } \\
\text { markup ratio } \omega\end{array}$ \\
\hline 0.60 & 0.60 & -0.21 & 0.06 \\
0.70 & 0.62 & -0.20 & 0.13 \\
0.80 & 0.68 & -0.18 & 0.29 \\
0.89 & 0.95 & -0.07 & 0.75 \\
0.90 & 1.02 & -0.04 & 0.84 \\
0.95 & 1.60 & 0.20 & 1.24 \\
\hline
\end{tabular}

Source: Author's calculations.

a. Probability that the price remains fixed in a given quarter.

Table 5 reports the multipliers corresponding to varying degrees of price stickiness, as controlled by the parameter $\theta$. A value of $\theta$ between 0.8 and 0.9 delivers an output multiplier in the range just below 1 and a consumption multiplier that is only barely negative. The implied frequency of price change is between 20 percent and 10 percent per quarter. Christiano, Eichenbaum, and Rebelo (2009) take $\theta$ to be 0.85 .

I conclude that the reduced-form approach taken in this paper, based on a negative elasticity of the markup ratio with respect to output, provides a reasonable basis for inferring the effects of changes in government purchases on output and consumption. From the perspective of the issues studied in this paper, it is not necessary to take separate stands on the various ingredients of a nominal model, including the frequency of price adjustment and the response of the central bank. What matters is the reduction in the markup when output expands. The model here is compatible with any explanation for that negative relationship, including explanations that do not depend on sticky prices, such as that of Rotemberg and Garth Saloner (1986).

\section{IV.B. The Importance of the State of the Economy}

The output and consumption multipliers are derivatives of two endogenous variables with respect to an exogenous shock. They are not fundamental structural parameters invariant to the state of the economy. Quite the contrary, the multipliers are themselves endogenous. The state of the economy in 2009 provides a perfect example. With extreme slack in the economy and the federal funds rate at essentially zero, there are good reasons to believe that the government purchases multipliers are higher than in normal times. 
Christiano, Eichenbaum, and Rebelo (2009) find that the government purchases multiplier in a New Keynesian model becomes large when the economy hits the zero nominal interest rate bound. In a model with an output multiplier of 0.9 in normal times, the multiplier rises to 3.9 when the nominal bank interest rate hits the zero bound and the central bank loses the ability to stimulate the economy by cutting that interest rate.

In the simple New Keynesian model of the previous section, the central bank follows a Taylor rule that increases the nominal interest rate by 1.5 percentage points for each percentage point of inflation. At the zero bound, the coefficient becomes zero. The output multiplier rises from 0.95 to 1.72 and the consumption multiplier from -0.07 to 0.26 .

\section{IV.C. The Wealth Effect}

Much of the modern literature on multipliers takes the key difference between neoclassical real business cycle (RBC) models and traditional models to be the former's inclusion of a wealth effect on consumption. Galí, López-Salido, and Vallés (2007, p. 228, footnotes omitted) provide a clear statement of the standard view of the difference between the two models:

\footnotetext{
The standard RBC and the textbook IS-LM models provide a stark example of such differential qualitative predictions. The standard RBC model generally predicts a decline in consumption in response to a rise in government purchases of goods and services (henceforth, government spending, for short). In contrast, the IS-LM model predicts that consumption should rise, hence amplifying the effects of the expansion in government spending on output. Of course, the reason for the differential impact across those two models lies in how consumers are assumed to behave in each case. The RBC model features infinitely-lived Ricardian households, whose consumption decisions at any point in time are based on an intertemporal budget constraint. Ceteris paribus, an increase in government spending lowers the present value of after-tax income, thus generating a negative wealth effect that induces a cut in consumption. By way of contrast, in the IS-LM model consumers behave in a non-Ricardian fashion, with their consumption being a function of their current disposable income and not of their lifetime resources. Accordingly, the implied effect of an increase in government spending will depend critically on how the latter is financed, with the multiplier increasing with the extent of deficit financing.
}

A related issue is that some critics of the use of temporary increases in government purchases have argued that their effect is blunted by the public's expectation of higher future taxes. The model says the opposite: the expectation of higher future taxes lowers wealth, stimulates work effort, and discourages consumption. The output multiplier is higher and the consumption multiplier more negative in a model with the wealth effect than without it. Other critics believe that the public is unaware of the future burden of higher government purchases and are skeptical of 
stimulus estimates that include the wealth effect. To evaluate this issue, I examined the response of the model with elastic labor supply and an elasticity of the markup with respect to output, $\omega$, of 0.6 to an immediate increase in purchases followed by a decline at a rate of 30 percent per year. This model embodies the wealth effect. I compared the multipliers in that model with those in an otherwise identical model in which the increase in immediate purchases was paid back, so to speak, by a decrease in purchases at the end of the solution period with the same present value. Recall that the immediate increase is $g$, the persistence rate is $\phi$, and the economy's discount factor is $\beta$. The repayment in the last period is

$$
\left(\frac{1}{\beta}\right)^{T} \frac{g}{1-\beta \phi}
$$

This alteration in the model lowers the output multiplier by 0.022 and makes the consumption multiplier 0.001 point more negative. These changes are in the expected direction but are trivial in magnitude. I conclude that it hardly matters whether the public anticipates the future taxes needed to finance a temporary increase in government purchases. Ricardian neutrality is irrelevant in this respect.

This calculation also demonstrates the unimportance of the wealth effect for temporary increases in government purchases. The standard view, quoted above, applies to permanent increases but not to the type of temporary increase that occurs in a countercyclical stimulus.

\section{Sticky Wages}

The results so far rely on what I have elsewhere called "equilibrium wage stickiness" (Hall 2005). The wage and the volume of work together represent an equilibrium in the bargain between worker and employer, but because the wage responds weakly to changes in labor demand, employers find it desirable to recruit more aggressively when demand is strong; their efforts tighten the labor market and reduce unemployment. An earlier view of wage stickiness rejects the equilibrium concept and supposes that the wage can be sticky in the sense of preventing a worker-employer pair from achieving bilateral efficiency. Hall (2009) argues that this disequilibrium sticky-wage view is unnecessary to an understanding of employment fluctuations-equilibrium stickiness is enough. Here, on the 
contrary, I explore briefly the implications of an extreme form of disequilibrium sticky wages, namely, a fixed real wage. For a discussion of the details of a different and less extreme form in New Keynesian models based on Calvo wage setting, see Jesús Fernández-Villaverde and Juan Rubio-Ramírez (2009). This version of the model differs from the earlier version in that the consumption-work effort condition of equation 19 no longer holds, and the wage $w$ is now fixed at its stationary value for the baseline level of government purchases. The effect is to make labor supply infinitely elastic at the fixed wage, rather than fairly elastic around a wage determined by wealth.

The fixed-wage model implies that the output and consumption multipliers are exactly zero. Absent the markup response, this proposition follows directly from the observation that firms hire up to the point that the marginal revenue product of capital equals the wage. The response of the markup does not alter this proposition. Putting the markup response into the profitmaximization condition for the firm's choice of labor input and restating in terms of labor input $h_{1}$ and capital $k_{0}$ yields what I call the extended labor demand function:

$$
h_{1}=\left[\alpha k_{0}^{(1-\alpha)(1+\omega)} \frac{1}{w}\right]^{\frac{1}{1-\alpha(1+\omega)}} .
$$

With $k_{0}$ at its historical, preshock level, the only potentially endogenous variable here is the wage. If it is fixed, labor input in the first postshock period is also fixed, and so output and consumption are fixed.

By contrast, in the baseline model of this paper, where the wage is endogenous, a change in the wage can alter employment and output. Now comes the surprise: the labor demand function extended to include the markup response, in the above equation, slopes upward! In the base case $\alpha=0.7$ and $\omega=0.7$, so $1-\alpha(1+\omega)=-0.19$, and the exponent on the wage in the extended labor demand function is more than 5 . The baseline model gets its brisk response of employment and output from a small wage increase that stimulates both demand and supply.

In the fixed-wage case, a strong response does emerge once time goes by and the capital stock expands, thus increasing labor demand. Figure 2 compares the impulse response functions for the fixed-wage and the baseline models. The fixed-wage response builds slowly for an extended period. Output remains high even 15 years after the shock to government purchases, many, many years after purchases have returned to normal. 
Figure 2. Impulse Response Functions for the Baseline and Fixed-Wage Models

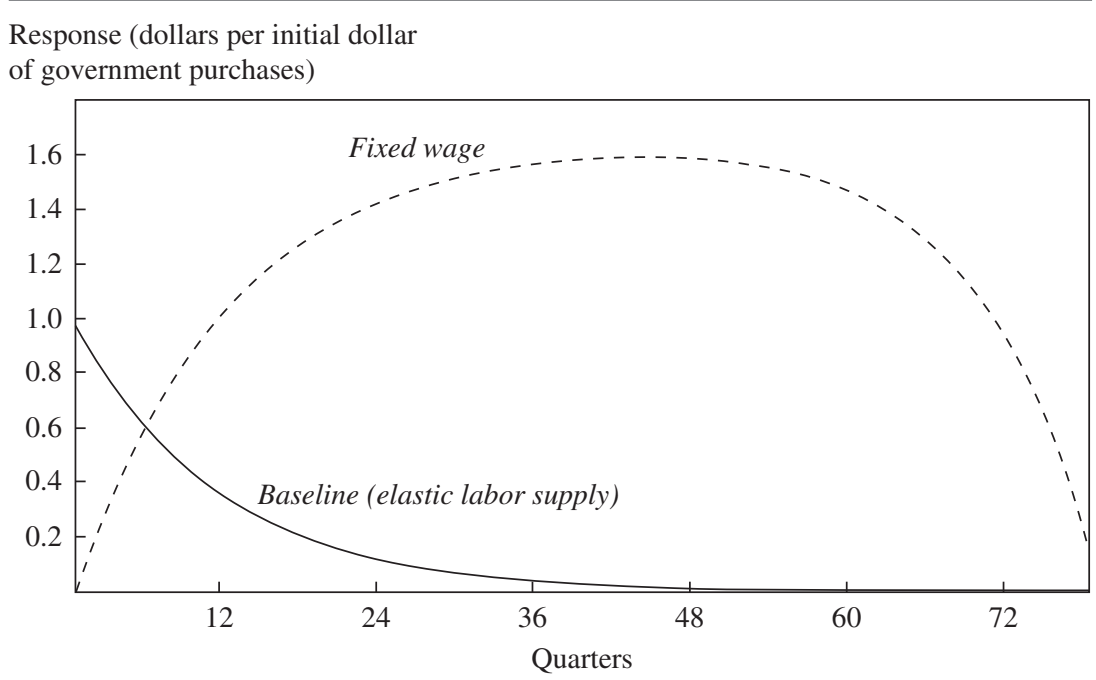

Source: Author's calculations.

\section{Departures from the Life-Cycle Model of Consumption}

One of Keynes's contributions to macroeconomic theory was the consumption function, where current consumption depends mainly on current income. As the life-cycle model became the standard framework for thinking about consumption behavior, researchers developed hybrid models in which some households have full access to capital markets, and therefore smooth consumption according to the life-cycle principle, while othersthose who would borrow if they could - are constrained to consume current income. Despite a quarter century of research within this framework, substantial disagreement prevails about the fraction of consumption governed by the life-cycle model. Note that the issue is the fraction of consumption, not the fraction of consumers. Given that more prosperous households are surely less likely to be constrained, the fraction of constrained consumption is less than the fraction of constrained consumers.

To the extent that the factual premise of this paper holds - that the output response to government purchases is robust and close to dollar for dollar, whereas the consumption response is essentially zero-the idea that consumption responds mainly to current income is completely unsupported. The reason is that the ratio of the consumption response to the output response is the perfect instrumental variables estimator of the marginal 
propensity to consume if a simple consumption function links output (income) and consumption. If one takes the evidence in table 1 seriously, the marginal propensity to consume is slightly negative and estimated with precision, provided at least the Korean War is included in the sample. Obviously, a negative marginal propensity to consume is profoundly inconsistent with the idea of a consumption function, so the appropriate conclusion is that important forces other than current income, such as the forces implicit in the life-cycle model, determine consumption. Despite the problems with inference based on the behavior of consumption during wars, I think the hypothesis that current income has a large effect on consumption faces an uphill battle with the data.

The standard view of the government purchases multiplier-as expressed, for example, in the quote from Galí and coauthors in the previous sectionis that a Keynesian consumption function delivers fairly high multipliers.

If the consumption function reflects borrowing constraints on the unemployed, some alteration of the labor supply part of the earlier model is needed: the notion of a constraint takes labor income as exogenous, not partly the choice of the worker. The development of a full model with heterogeneous households, some facing more limited choices than discussed earlier, is beyond the scope of this paper. Instead, I will pair the consumption function with another assumption of many Keynesian models, that of wage rigidity, as discussed in the previous section. Employers choose total hours of work, $h$, so as to equate the marginal revenue product of labor to the prescribed wage. I drop both the consumption Euler equation (equation 21) and the first-order condition for labor supply (equation 19) and replace them with a Solow-style consumption function,

$$
c_{t}=(1-s) y_{t},
$$

and the earlier assumption that the wage is a constant, $\bar{w}$. For consistency with the other results in this paper, I choose the saving rate $s$ to be its stationary value in the neoclassical model, just under 0.2. Note that this is the saving rate out of gross output and includes depreciation, which is why it exceeds normal ideas about net saving, which treat it as saving out of income net of depreciation.

The relevant equations from the earlier model are the equation for employment conditional on the wage $w$ (equation 24), evaluated at $w=\bar{w}$, and the law of motion of the capital stock,

$$
k_{t}+\frac{\kappa}{2} \frac{\left(k_{t}-k_{t-1}\right)^{2}}{k_{t-1}}=(1-\delta) k_{t-1}+y_{t}-c_{t}-g_{t} .
$$


Figure 3. Impulse Response Functions for the Fixed-Wage Model with Consumption Proportional to Output

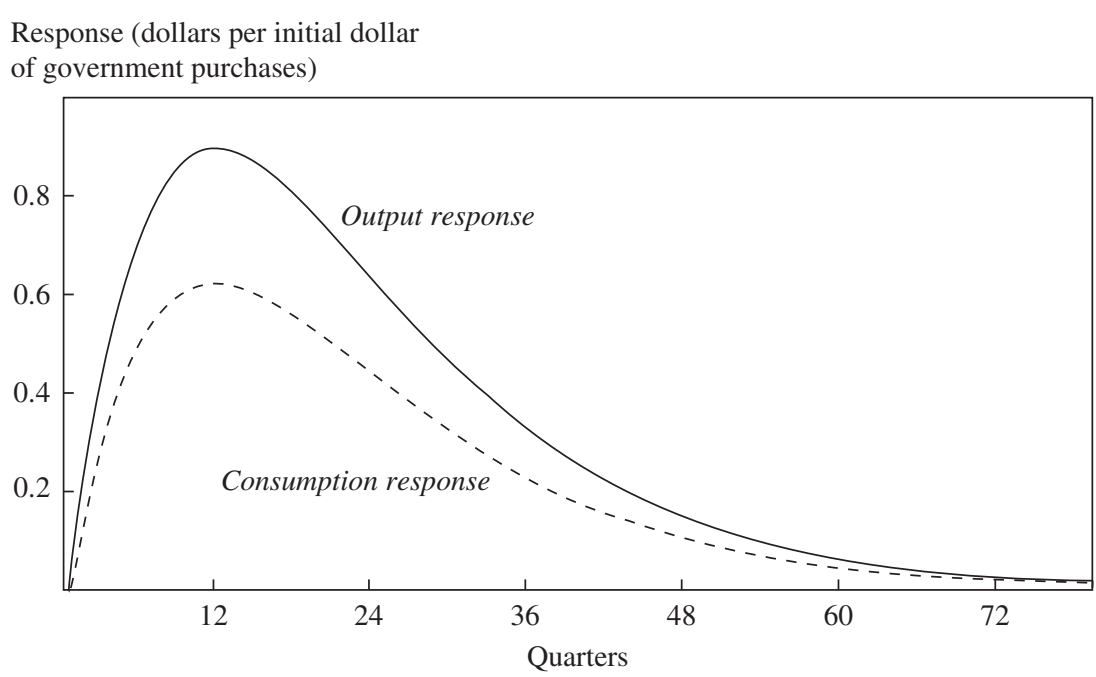

Source: Author's calculations.

The model behaves as a Solow growth model, converging to stationary values of output, capital, and consumption, which I take to equal their values in the baseline model.

Figure 3 shows the impulse response functions for the consumption function model. Because the model embodies a fixed wage, the immediate response of both output and consumption is zero. The responses build over time but are not as strong as in the case of a fixed wage as shown in figure 2 . Not surprisingly, the simple consumption function delivers a distinctly positive consumption multiplier, not far below the output multiplier. The intertemporal substitution response that depresses consumption in the model with life-cycle consumption is absent.

The relationship between this model and the simple expenditure model of the purchases multiplier is easy to explain. The simple expenditure model takes investment as exogenous. Letting $i$ denote investment and neglecting time subscripts,

$$
y=\frac{i+g}{s},
$$

the standard expenditure solution with multiplier $m_{y}=1 / s$. In contrast, the consumption function model makes investment endogenous, declining when 
output rises. Government purchases crowd out investment in this model. Because consumption has to rise by more than 80 percent of the increase in output, crowding out is severe in the presence of a consumption function.

A number of investigations of the role of partial borrowing constraints, discussed in the next section, suggest that they can increase the output multiplier under conditions different from the model studied here, which is extreme. This model takes wages as fixed for 20 years, and it assumes that all consumption is tied to current income, contrary to the conclusions of the literature on borrowing constraints.

\section{Multipliers Inferred from New Keynesian Structural Models}

The term "New Keynesian" refers to the class of models combining a full treatment of the production side of the economy, life-cycle consumption behavior, sticky wages, and markup ratios that respond negatively to output increases because of sticky prices. Another name often used for the class is dynamic stochastic general-equilibrium or DSGE models. These models are widely used in recent macroeconomic research, especially at central banks. Although the characterization of the effects of monetary policy has been the main use of New Keynesian models, four studies have examined responses to government purchases.

Galí, López-Salido, and Vallés (2007) consider a fairly standard New Keynesian model, with one nonstandard element: a fraction of consumers $\lambda$ simply consume all their labor income rather than follow the life-cycle principle. Although these authors also consider a competitive labor market with a flexible wage, I will discuss only their results for a sticky wage, for the reasons discussed earlier in this paper: a sticky wage appears to be essential to generate meaningfully positive government purchases multipliers. The results of Galí and coauthors confirm this proposition. In their baseline model, they take the quarterly persistence of the effect of the government purchases shock to be 0.9 , about the same as the annual persistence of 0.7 that I used earlier. At their preferred value of the fraction of consumption subject to rule-of-thumb behavior, $\lambda=0.5$, the output multiplier on impact is 1.9 and the consumption multiplier is 1.0 (Galí and others 2007, figure 3, p. 250). With life-cycle consumption behavior, $\lambda=0$, the output multiplier is 0.75 and the consumption multiplier is slightly negative. Intermediate values of $\lambda$ come close to matching the consumption multipliers found in the VARs reviewed earlier in this paper. 
López-Salido and Pau Rabanal (2006) find similar results in a model based on a leading New Keynesian model, that of Christiano, Eichenbaum, and Evans (2005). With some consumption governed only by current income and the remainder by the life-cycle principle, the impact output multiplier is just above 2 and the consumption multiplier just above 1 (Christiano and others 2005, figure 1, p. 19). With the standard New Keynesian specification where all consumption follows the life-cycle principle, the output multiplier is slightly above 1.0 and the consumption multiplier is slightly negative.

Günter Coenen and Roland Straub (2005) study the New Keynesian model of Frank Smets and Raf Wouters (2003), an outgrowth of the Christiano, Eichenbaum, and Evans model. They consider both the original model and one altered so that about a quarter of consumption tracks current income rather than following the life-cycle principle. For the original model, the consumption multiplier is -0.14 on impact, and the output multiplier is 0.68 ( 1 plus the consumption multiplier of -0.14 plus the investment multiplier of -0.18) (Smets and Wouters 2003, figure 1, p. 457). When about a quarter of consumption is constrained, the consumption multiplier is -0.05 on impact, and the output multiplier is 0.77 ( 1 plus the consumption multiplier of -0.05 plus the investment multiplier of -0.18).

John Cogan and coauthors (2009) also use the Smets-Wouters New Keynesian model to measure the output multiplier. Their model assumes that all consumption follows the life-cycle principle. For the transitory burst of government purchases in the February 2009 stimulus bill, they find an output multiplier of about 0.5 (Cogan and others 2009, figure 2, p. 12).

These four papers make similar assumptions about the single most important feature of a model with respect to multipliers, namely, the response of the markup ratio to increases in output. The first two illustrate the importance of the controversial issue of the fraction of consumption governed by the life-cycle principle. Absent a substantial departure from the life-cycle principle, the models agree that the output multiplier is between 0.5 and 1.0 and that the consumption multiplier is around zero, values consistent with the OLS and VAR evidence.

\section{Negative Response of the Markup Ratio to Output}

Rotemberg and Woodford (1999) provide a complete discussion as of a decade ago of the many empirical and theoretical issues relating to variations in the markup ratio. 


\section{VIII.A. Earlier Research on Cyclical Changes in the Markup}

Research on variations in the markup of price over marginal cost falls into two categories: models where alterations in competition are a driving force of the business cycle or are part of such a driving force, and models where markups fall passively when output expands, because product prices are sticky but some elements of cost are not. For purposes of understanding the effects of fiscal policy, the issue is the markup, not price stickiness itself. Thus, both strands of research are relevant to the issue of the output multiplier for government purchases. One easy way to tell the two strands apart is to see whether sticky prices are derived, as in the first set of models, or assumed, as in the second. From the perspective of the fiscal issue, it does not seem to matter which way the model gets to the property of a countercyclical markup. Rotemberg and Woodford (1999, pp. 1112-29) survey this literature thoroughly.

\section{VIII.B. Theoretical Models with Countercyclical Markup}

Rotemberg and Saloner (1986) launched the modern literature on the relationship between competition and economic activity. The starting point is a model of oligopoly in which a collusively determined high price is an equilibrium because rivals will revert to competition to punish a deviator who tries to capture a large volume of sales by beating its rivals' price for one period. The potential deviator compares the immediate profit in one period with the present value of its share of the collusive profit. Deviation is more likely when demand is temporarily strong, so that the immediate profit exceeds that present value. Some episodes in real-world oligopolies seem to fit the model.

Rotemberg and Woodford (1992) carried the idea of a declining markup in a boom over to a general-equilibrium setting. Since the publication of their well-known paper, it has been understood that a countercyclical markup is an important ingredient in models that take demand fluctuations as a driving force.

Miles Kimball (1995) provides an extensive discussion of the role of markup variation in a sticky-price New Keynesian setting.

Mark Bils (1989) developed a model of countercyclical markups based on customer loyalty. In an expanding economy where customers are seeking suppliers of products they have not previously consumed, sellers compete aggressively and customers enjoy low prices. Markups are low. In a slump, customers buy from their established suppliers and do not look 
for suppliers of new goods. Sellers respond by setting higher prices to reflect the less elastic demand of their customer base.

Chris Edmond and Laura Veldkamp (2009) consider the effect of changes in the distribution of income over the business cycle. They conclude that booms are periods when income shifts toward lower-income consumers with more elastic demand, so that the optimal markups of sellers fall. To the extent that increases in government purchases compress the distribution of income in the same way as other driving forces, this mechanism would support the assumption in this paper about the negative relationship between output and markups.

\section{VIII.C. Empirical Research on the Cyclical Movements of the Markup Ratio}

If the markup ratio falls in booms and rises in recessions, the share of income captured by labor should rise in booms and fall in recessions, given that the markup adds to the income of business owners. In other words, labor's share should be procyclical. To formalize this idea, note that marginal cost is

$$
\frac{w}{\partial Y / \partial L}
$$

where $w$ is the wage, $Y$ is output, and $L$ is labor input. This relationship comes from the envelope theorem property that a cost-minimizing firm is indifferent among increases in any of its inputs. Then the markup ratio $\mu$ is

$$
\begin{aligned}
\mu & =\frac{p}{\frac{w}{\partial Y / \partial L}} \\
& =\frac{p Y}{w L} \frac{L}{Y} \frac{\partial Y}{\partial L} \\
& =\frac{\alpha}{s},
\end{aligned}
$$

where $\alpha$ is the elasticity of output with respect to labor input and $s$ is the share of labor compensation $w L$ in total revenue $p Y$. If the elasticity $\alpha$ is constant - the Cobb-Douglas case- the intuition about the relationship 
Figure 4. Markup Ratio and Employment, 1948-2009

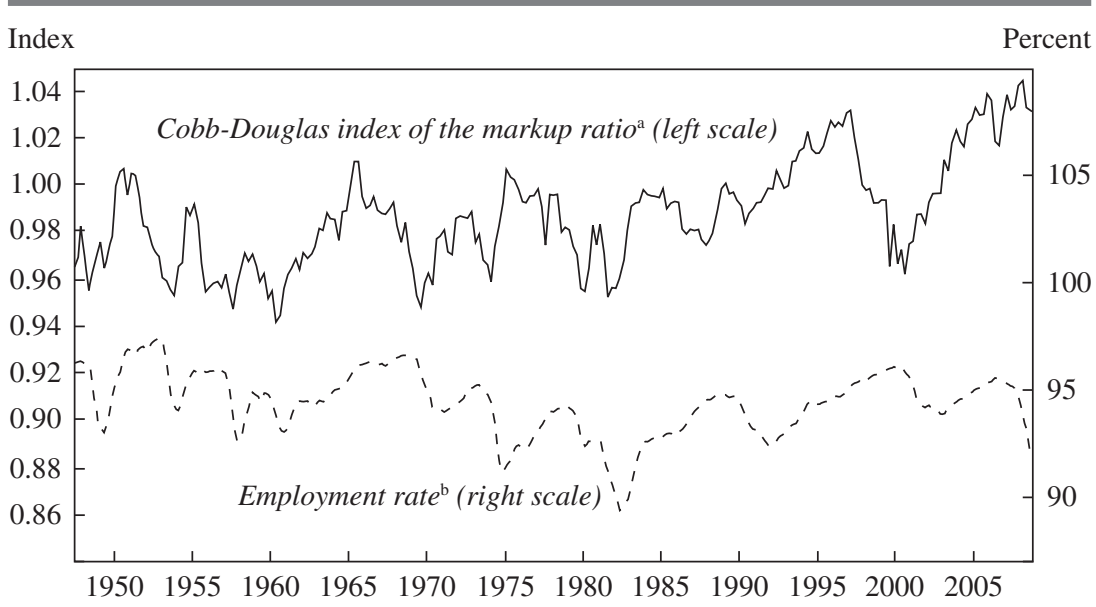

Source: Author's calculations.

a. Reciprocal of the Bureau of Labor Statistics index of the labor share of income.

b. One minus the unemployment rate.

between labor's share and the markup is confirmed: a countercyclical markup requires a procyclical labor share.

To check this proposition against U.S. data, I construct two series from Bureau of Labor Statistics (BLS) data. One is the reciprocal of the BLS index of the labor share (BLS series PRS84006173), which I call the Cobb-Douglas index of the markup ratio. The other is the employment rate, which is 100 minus the standard unemployment rate (BLS series LNS14000000). According to the simplest version of the countercyclical markup hypothesis, the markup index should move in the opposite direction from the employment rate: as employment grows in a boom, the markup index should decline.

Figure 4 shows the two series. Although their relationship is far from systematic, it is clear that they tend to move in the same direction: booms are times when the markup index rises along with employment, and recessions are times when the markup index falls with employment. To put it differently, business owners' share of income does not fall in booms, on account of lower markups; rather, it rises. The two most recent expansions are the leading examples of declining labor and rising business shares; the markup index reached an all-time high at the most recent cyclical peak at the end of 2007. 
Figure 4 is only a first cut at testing the countercyclical markup hypothesis. Research has focused on two factors omitted from the figure. One is the measurement of the labor share of compensation. In the numerator of the share, $w L$, the appropriate measure of the wage is the marginal cost to the firm of adding another hour of work. If the incremental hour is more expensive than the average hour, the use of the average wage in the numerator will understate the true value of labor's share. If the understatement were the same in booms and slumps, it would not affect the conclusion to be drawn from the figure. But if the incidence of higher marginal wages is greater in booms than in slumps, the properly calculated share will be less countercyclical than the one based on the average wage, and the Cobb-Douglas index will be less procyclical or possibly even countercyclical, as the hypothesis requires. Bils (1987) pursued this approach.

The second factor omitted from the figure is variation in the elasticity of the production function, $\alpha$. If the elasticity of substitution between labor and capital is less than 1 , the elasticity falls if the labor-capital ratio rises: low substitution means that production saturates in one input if that input rises relative to another. The markup ratio is the elasticity divided by the labor share. If the elasticity falls more than in proportion to the labor share as the economy expands, the true markup ratio could fall even though the Cobb-Douglas index of the markup ratio rises. Christopher Nekarda and Ramey (2009) pursue this approach. They conclude that the variation in the labor elasticity of the production function with an elasticity of substitution of 0.5 is insufficient to deliver a countercyclical markup ratio.

Bils (1987) estimated the cyclical movements in the markup ratio by estimating the changes in the marginal cost of labor and applying the envelope theorem to infer changes in the marginal cost of output. He found that a larger fraction of workers are subject to the 50 percent overtime premium requirement of the Fair Labor Standards Act in booms than in recessions. Given that employers could have avoided the increase in the marginal cost of labor by using more of other factors, but did not, he inferred a corresponding increase in the marginal cost of output. Then he found that prices are not as cyclical as marginal cost, leading to the inference that the markup of price over marginal cost must shrink in booms and widen in recessions. Nekarda and Ramey (2009) revisit Bils's findings in much the same framework, but with new, broader data and sufficient alterations to reverse the finding in favor of procyclical markup ratios. They discuss evidence that the effective overtime premium is not the statutory 50 percent that 
Bils used, but rather may be 25 percent. They also question the definition of the business cycle that Bils employed. Extension from manufacturing to the entire economy appears to be the most important factor distinguishing their work from Bils's.

The framework in Bils's and in Nekarda and Ramey's work is robust in a number of important ways. First, it makes no assumptions about the supply of capital services. The results apply with any type or magnitude of capital adjustment costs and variable utilization of installed capital (see Rotemberg and Woodford 1999, p. 1079). Second, they apply for any type of pricing, including customer pricing where the choice of the price depends on complicated intertemporal factors. The price is taken as data. Customer pricing should be visible in the data as higher profits and lower labor shares in slack markets, when firms are exploiting their installed base. Firms should forgo profit in strong markets, when it pays to set prices low to sign up new customers who will remain loyal when conditions weaken.

One important factor bearing on the measurement of cyclical fluctuations in markup ratios has escaped empirical consideration so far, to my knowledge. Employers may smooth wage payments to their workers rather than pay a wage equal to current marginal revenue product, as assumed in the research on the cyclical behavior of the labor share. Jonathan Thomas and Tim Worrall (1988) present a representative model where employers insure workers against some of the idiosyncratic risk of working for a particular firm. In their model the wage payment remains constant as long as it remains within the bargaining set of the worker and the firm. For employment relationships with substantial match-specific capital, the wage can remain constant despite large changes in demand for the firm's products. The result is a substantial bias in favor of a countercyclical labor share and thus a procyclical markup ratio. Although this issue is well understood, no good solution has appeared so far.

Pissarides (2009) surveys the literature on wage flexibility and finds a strong consensus that the wages of newly hired workers are more sensitive to the business cycle than are the wages of continuing workers. This finding supports the hypothesis of wage smoothing.

I conclude that the cyclical behavior of the labor share does not provide direct support for the hypothesis of a countercyclical markup ratio. The simple Cobb-Douglas markup ratio derived from the labor share is distinctly procyclical. Attempts to adjust it through improved measurement of the marginal wage and through consideration of fluctuations in the labor 
elasticity of the production function do not seem to deliver big enough adjustments to overcome this procyclical character. In the absence of effective adjustments for wage smoothing, however, I believe the hypothesis of a countercyclical markup ratio is still an open issue.

\section{VIII.D. Indirect Evidence on the Cyclical Behavior of the Markup Ratio}

Bils and James Kahn (2000) use inventory movements to shed light on the cyclical movements of marginal cost. Earlier research, based on a fixed target ratio of inventories to sales, had concluded that procyclical inventory investment showed that marginal cost falls in booms, because otherwise firms would schedule the investment during times when production was cheap, in times of low output. Bils and Kahn demonstrate that the movements of marginal cost cannot be big enough to induce such rescheduling of production. They go on to show that countercyclical markups do alter inventory holding cost enough over the cycle to explain the movements of inventories, if the target inventory-sales ratio is itself sensitive to the holding cost, given an extreme assumption about the cost of labor. The assumption is that all of the procyclical movement of measured productivity is actually variation in work effort. Under this assumption, labor becomes cheap in booms of the type that last occurred in the early 1980s, in the recovery following the recession of 1981-82. That assumption is not only extreme but unverifiable. In any case it fails to account for the events of the following three business cycles, when productivity rose during recessions. It strains credulity that people were working harder than usual in the troughs of 1991, 2001, and today.

Research on the response of prices to cost increases has some bearing on the behavior of the markup ratio. To the extent that prices remain fixed when costs rise, the markup ratio falls. As I noted earlier, models incorporating the popular Calvo price-stickiness mechanism have this property. Bils and Yongsung Chang (2000) studied highly disaggregated prices. They found stronger responses of prices to changes in materials and fuel costs than to changes in wages, productivity, and output (taken as a measure of the position of the firm on its marginal cost schedule). The weaker response to wages is consistent with wage smoothing, which introduces an error of measurement. The quick response to certain categories of cost is inconsistent with the Calvo model. Bils and Chang favor theories of price stickiness based on modern limit pricing models, where firms deter entry of rivals by depressing the profits available to entrants. 
Table 6. Effects of the February 2009 Stimulus Measure and of an Alternative, Front-Loaded Measure

\begin{tabular}{|c|c|c|c|c|}
\hline Item & 2009 & 2010 & 2011 & Sum \\
\hline $\begin{array}{l}\text { Actual stimulus purchases, fiscal year } \\
\text { (billions of dollars) }\end{array}$ & 34.8 & 110.7 & 76.3 & 221.8 \\
\hline $\begin{array}{l}\text { Actual stimulus purchases, calendar year }{ }^{\mathrm{a}} \\
\text { (billions of dollars) }\end{array}$ & 62.5 & 102.1 & 57.2 & 221.8 \\
\hline GDP (billions of dollars) & 13,700 & 14,043 & 14,604 & \\
\hline $\begin{array}{l}\text { Actual stimulus purchases, calendar year } \\
\text { (percent of GDP) }\end{array}$ & 0.46 & 0.73 & 0.39 & 1.57 \\
\hline Effect on GDP (percent) & 1.10 & 1.28 & 0.70 & 3.08 \\
\hline $\begin{array}{l}\text { Hypothetical front-loaded stimulus purchases, } \\
\text { calendar year (percent of GDP) }\end{array}$ & 0.71 & 0.50 & 0.35 & 1.56 \\
\hline Effect on GDP (percent) & 1.35 & 0.94 & 0.62 & 2.90 \\
\hline
\end{tabular}

Sources: Congressional Budget Office; author's calculations.

a. A small amount of purchases, projected by the Congressional Budget Office to occur in fiscal 2012, is omitted from the figure for calendar 2011.

\section{Application to the Government Purchases Stimulus of 2009}

The fiscal stimulus measure passed in February 2009 included increases in federal purchases of goods and services. The top row of table 6 gives the Congressional Budget Office's estimates of likely purchases under the measure by fiscal year (October through September). The second row restates the figures by calendar year, assuming equal spending within the fiscal year by quarter. The third row gives rough estimates of GDP for the three years 2009, 2010, and 2011, and the fourth row states the stimulus purchases as percents of GDP. The fifth row shows the results of inserting the fourth row into the model with the preferred parameter values. These are the base case values in table 3, but with the markup-response parameter $\omega$ set at 1.29 to match the response in the New Keynesian model at the constant nominal interest rate of zero that prevailed when the policy was adopted in February 2009. I substitute the fourth row into the model in place of the exponentially declining pattern used in the earlier runs of the model. This row shows the powerful anticipation effects in the model, based on the assumption that, as of the beginning of 2009, decisionmakers believed that purchases of the magnitude shown in the table would materialize in the three years. The purchases stimulus raises GDP in 2009 by 1.10 percent, with further effects of 1.28 percent in 2010 and 0.70 percent in 2011. The model disputes the common view that the long ramp-up in purchases will delay the effects of the stimulus until long after they would 
be most beneficial. Rather, announcing future purchases delivers immediate stimulus. Back-loading is a desirable feature of a stimulus program. All this is according to a simple model that overlooks many potentially important features of the economy. The calculations also rest critically on the projection that the stimulus purchases will ramp down in 2011 and end in 2012, a proposition that is under dispute.

The bottom two rows of table 6 show the effects of an alternative, frontloaded time pattern of stimulus purchases. I assume, as in the earlier runs of the model, that a burst of new purchases dies off at 30 percent per year rather than rising in the second year. Unlike in the earlier runs, here the purchases go to zero in the fourth year, to make the policy more comparable to the three-year horizon of the February 2009 stimulus measure. I standardize the front-loaded policy to have the same total amount of purchases over the three years. The effect in 2009 is somewhat larger in the front-loaded case than in the actual back-loaded policy, but the three-year sum of the effects on GDP of the front-loaded policy is smaller. The model suggests that the much-criticized slow ramp-up of the stimulus was actually beneficial.

Table 6 makes it clear that the purchases component of the stimulus package passed in February 2009 could not possibly have closed much of the shortfall of GDP from normal levels. The shortfall is around \$1.2 trillion for 2009. No conceivable multiplier could permit $\$ 62.5$ billion of added purchases to close much of a gap of that magnitude.

\section{Concluding Remarks}

I am persuaded that GDP rises by roughly the amount of an increase in government purchases, and possibly rather more when monetary policy is passive because of the zero bound. I am aware that neoclassical models have no hope of explaining such a high multiplier, even if extended to include unemployment along the lines discussed in this paper. I am impressed by the success of New Keynesian models in matching the observed multiplier, because these models were developed for rather different purposes and estimated using data containing essentially no variation in government purchases.

Notwithstanding this success, I am concerned about the weak factual support for the key mechanism underlying the New Keynesian explanation of the multiplier, namely, the decline in the markup ratio that accompanies an increase in output. The behavior of profit margins suggests on its face that the markup ratio rises with output. The only plausible way for falling 
markups to fit the data is through a lot of wage smoothing. I think there is room for new ideas outside the New Keynesian framework to explain the high value of the multiplier along with other mysteries about aggregate economic behavior.

ACKNOWLEDGMENTS I am grateful to the editors and to my Brookings Panel discussants, and to Robert Barro, Susanto Basu, Jordi Galí, Jonathan Parker, Fabrizio Perri, Valerie Ramey, and Ricardo Reis for guidance and comments. A file containing the calculations is available on my website. 


\section{References}

Aguiar, Mark, and Erik Hurst. 2005. "Consumption versus Expenditure." Journal of Political Economy 113, no. 5 (October): 919-48.

Andolfatto, David. 1996. "Business Cycles and Labor-Market Search.” American Economic Review 86, no. 1: 112-32.

Barro, Robert J., and Charles J. Redlick. 2009. "Macroeconomic Effects from Government Purchases and Taxes." Working Paper no. 15369. Cambridge, Mass.: National Bureau of Economic Research (September).

Bilbiie, Florin O. 2009. "Nonseparable Preferences, Fiscal Policy Puzzles and Inferior Goods." Journal of Money, Credit, and Banking 41, no. 2-3: 443-50.

Bils, Mark. 1987. "The Cyclical Behavior of Marginal Cost and Price." American Economic Review 77, no. 5 (December): 838-55.

1989. "Pricing in a Customer Market." Quarterly Journal of Economics 104, no. 4 (November): 699-718.

Bils, Mark, and Yongsung Chang. 2000. "Understanding How Price Responds to Costs and Production." Carnegie-Rochester Conference Series on Public Policy 52: 33-77.

Bils, Mark, and James A. Kahn. 2000. "What Inventory Behavior Tells Us about Business Cycles." American Economic Review 90, no. 3 (June): 458-81.

Blanchard, Olivier, and Jordi Galí. 2007. "Real Wage Rigidities and the New Keynesian Model." Journal of Money, Credit, and Banking 39, no. 1: 35-65.

Blanchard, Olivier, and Roberto Perotti. 2002. "An Empirical Characterization of the Dynamic Effects of Changes in Government Spending and Taxes on Output." Quarterly Journal of Economics 117, no. 4: 1329-68.

Calvo, Guillermo A. 1983. "Staggered Prices in a Utility-Maximizing Framework." Journal of Monetary Economics 12, no. 3 (September): 383-98.

Christiano, Lawrence J., Martin Eichenbaum, and Charles L. Evans. 2005. "Nominal Rigidities and the Dynamic Effects of a Shock to Monetary Policy." Journal of Political Economy 113, no. 1: 1-45.

Christiano, Lawrence, Martin Eichenbaum, and Sergio Rebelo. 2009. "When Is the Government Spending Multiplier Large?” Working Paper no. 15394. Cambridge, Mass.: National Bureau of Economic Research (October).

Coenen, Günter, and Roland Straub. 2005. "Does Government Spending Crowd in Private Consumption? Theory and Empirical Evidence for the Euro Area." International Finance 8, no. 3: 435-70.

Cogan, John F., Tobias Cwik, John B. Taylor, and Volker Wieland. 2009. "New Keynesian versus Old Keynesian Government Spending Multipliers.” Working Paper no. 14782. Cambridge, Mass.: National Bureau of Economic Research (March).

Edmond, Chris, and Laura Veldkamp. 2009. "Income Dispersion and Countercyclical Markups.” Journal of Monetary Economics 56, no. 6: 791-804.

Fernández-Villaverde, Jesús, and Juan F. Rubio-Ramírez. 2009. "A Baseline DSGE Model." University of Pennsylvania (October). 
Galí, Jordi, J. David López-Salido, and Javier Vallés. 2007. "Understanding the Effects of Government Spending on Consumption." Journal of the European Economic Association 5, no. 1: 227-70 (March).

Hall, Robert E. 1986. "The Role of Consumption in Economic Fluctuations.” In The American Business Cycle: Continuity and Change, edited by Robert J. Gordon. University of Chicago Press for the National Bureau of Economic Research.

2005. "Employment Fluctuations with Equilibrium Wage Stickiness." American Economic Review 95, no. 1 (March): 50-65.

2009. "Reconciling Cyclical Movements in the Marginal Value of Time and the Marginal Product of Labor." Journal of Political Economy 117, no. 2 (April): 281-323.

Hall, Robert E., and Paul R. Milgrom. 2008. "The Limited Influence of Unemployment on the Wage Bargain." American Economic Review 98, no. 4 (September): 1653-74.

Kimball, Miles S. 1995. "The Quantitative Analytics of the Basic Neomonetarist Model." Journal of Money, Credit, and Banking 27, no. 4, part 2 (November): 1241-77.

Kydland, Finn E., and Edward C. Prescott. 1982. "Time to Build and Aggregate Fluctuations.” Econometrica 50, no. 6 (November): 1345-70.

López-Salido, J. David, and Pau Rabanal. 2006. "Government Spending and Consumption-Hours Preferences.” Working Paper no. 02/2006. Barcelona: la Caixa (November).

Merz, Monika. 1995. "Search in the Labor Market and the Real Business Cycle." Journal of Monetary Economics 36, no. 2: 269-300.

Mortensen, Dale T., and Christopher A. Pissarides. 1994. "Job Creation and Job Destruction in the Theory of Unemployment." Review of Economic Studies 61, no. 3: 397-415.

Mountford, Andrew, and Harald Uhlig. 2008. "What Are the Effects of Fiscal Policy Shocks?” Working Paper no. 14551. Cambridge, Mass.: National Bureau of Economic Research (December).

Nekarda, Christopher J., and Valerie A. Ramey. 2009. "The Cyclical Behavior of the Price-Cost Markup." University of California, San Diego (July).

Perotti, Roberto. 2008. "In Search of the Transmission Mechanism of Fiscal Policy." In NBER Macroeconomics Annual 2007, edited by Daron Acemoglu, Kenneth Rogoff, and Michael Woodford. MIT Press.

Pissarides, Christopher A. 2009. "The Unemployment Volatility Puzzle: Is Wage Stickiness the Answer?" Econometrica 77, no. 5: 1339-69.

Ramey, Valerie A. 2009. "Identifying Government Spending Shocks: It's All in the Timing." Working Paper no. 15464. Cambridge, Mass.: National Bureau of Economic Research (October).

Romer, Christina, and Jared Bernstein. 2009. "The Job Impact of the American Recovery and Reinvestment Plan" (January). Washington: Obama-Biden Transition Project. otrans.3cdn.net/45593e8ecbd339d074_13m6bt1te.pdf. 
Rotemberg, Julio J., and Garth Saloner. 1986. "A Supergame-Theoretic Model of Price Wars during Booms." American Economic Review 76, no. 3 (June): 390-407.

Rotemberg, Julio J., and Michael Woodford. 1992. "Oligopolistic Pricing and the Effects of Aggregate Demand on Economic Activity." Journal of Political Economy 100, no. 6 (December): 1153-1207.

1999. "The Cyclical Behavior of Prices and Costs." Chapter 16 in Handbook of Macroeconomics, vol. 1B, edited by John B. Taylor and Michael Woodford. Amsterdam: Elsevier.

Shimer, Robert. 2005. "The Cyclical Behavior of Equilibrium Unemployment and Vacancies." American Economic Review 95, no. 1: 24-49.

Smets, Frank, and Raf Wouters. 2003. "An Estimated Dynamic Stochastic General Equilibrium Model of the Euro Area." Journal of the European Economic Association 1, no. 5 (September): 1123-75.

Thomas, Jonathan, and Tim Worrall. 1988. "Self-Enforcing Wage Contracts." Review of Economic Studies 55, no. 4 (October): 541-53. 


\section{Comments and Discussion}

\section{COMMENT BY}

ALAN J. AUERBACH Robert Hall has produced a very useful paper that provides an overview of the literature and much additional analysis regarding the impact of government purchases on GDP. As the paper's title makes clear, the focus here is exclusively on the effects of government purchases, which now constitute just over half of all government spending exclusive of interest payments. The remainder of the government budget consists of transfer payments, which are typically lumped together with taxes when their effects on output are considered, because, like taxes, they have no direct impact on GDP; transfer payments affect GDP only through their impact on private consumption, private investment, and net exports.

Although national income accounting is a logical exercise based on reasonable, time-tested conventions, one should keep in mind that the distinctions in the accounts are sometimes more sharply drawn than the underlying reality. For example, if the government appropriates money for a "shovel-ready" project, this is considered a government purchase, even if the project is a classic Keynesian one in which the shovels are used to dig and fill in ditches. With very minor modification, this hypothetical program could just as easily have been classified as an expansion of transfer payments, with no direct impact on GDP. The change in classification would not affect the further macroeconomic consequences of the policy, but it would have a big effect on the policy's measured multiplier. Thus, care is needed in drawing conclusions about the relative effectiveness of purchases and transfer payments based on their relative multipliers, a caveat less relevant for the current paper than for the broader related literature. What is relevant even for an analysis exclusively of purchases is that their effects on consumption, investment, and net exports should depend on the nature of the purchase. For example, a productive government investment, 
unlike a disguised transfer payment, might raise the marginal product of private capital and therefore encourage private investment. This is a point worth keeping in mind when making conjectures about the effects of quickly adopted antirecession policies, and one of the many reasons why multipliers estimated using historical episodes might not apply in the present circumstances.

Hall's paper relies on the two main tools of the literature to draw conclusions about the effects of government purchases on output: simple time-series econometrics with relatively few restrictions imposed, and general-equilibrium simulation models based on structural equations, calibrated using parameters based on either auxiliary estimates or educated guesses guided by theory. Each tool has its advantages and disadvantages. Time-series methods reveal patterns actually present in the data, whereas a model's predictions are only as accurate as the model itself is realistic. But time-series methods may be only of limited use in predicting the effects of policies when either the policies or the economic environment departs from historical experience; a structural model can easily be used for such an exercise. The two approaches therefore are naturally complementary, and Hall utilizes them in this fashion. He asks whether a calibrated model can generate predictions that are consistent with the empirical evidence, as a way of assessing the validity of both the model and the time-series analysis.

The basic conclusion of this exercise is yes. In particular, Hall argues that the most plausible time-series estimates, which find that government purchases increase GDP overall but crowd out private consumption, are consistent with what is implied by models based on optimal household and firm behavior. In what is perhaps the paper's most valuable contribution, he further shows which elements of the model are critical to this result and which are not. In particular, the two critical elements to generating a large enough multiplier are very elastic labor supply and countercyclical producer markups. Somewhat less critical, but helpful in limiting the negative consumption response, are complementarity of work and consumption and limited-horizon consumption responses to changes in incomes, both of which have received some empirical support in the recent literature. And of little importance at all are wealth effects, since it does not take a very long horizon to get close to Ricardian equivalence when a temporary spending policy is being analyzed. As to the empirical support for the two key components, responsive labor supply and countercyclical markups, Hall argues that a very elastic employment response is consistent with equilibrium in a model of job search and wage bargaining even if the hours elas- 
ticity is small, and he suggests, less convincingly, that the jury is still out on the presence of countercyclical markups, even though they do not seem to be present in the data. In short, Hall tells a story that hangs together reasonably well, but not all the pieces fit quite right.

All in all, I find Hall's analysis to be relatively convincing as to the plausibility of the empirical results he reviews early in the paper. Like him, I find the most convincing results on the effects of government purchases to be those based on the methodology of Valerie Ramey and Matthew Shapiro (1998), recently updated by Ramey (2009), which use large military spending buildups to identify exogenous government spending shocks. As Hall himself illustrates nicely in his figure 1, however, these results are based on some very unique and now quite dated natural experimentsmostly World War II and the buildup to it—so it is very hard to know what they reveal about what is of greatest concern right now, namely, the effects of nonmilitary government purchases on economic activity when the economy is in deep recession, short-term government interest rates are effectively zero, and the government's ability to meet its fiscal commitments is quite unclear. Here one relies on the structural models, and there is little empirical evidence against which to test the models' predictions. The fact that they are consistent with the empirical results does not imply that they will do a very good job in 2009 , so one is still left having to evaluate the models by judging the plausibility of their assumptions.

To me, it is quite plausible - as argued by Lawrence Christiano, Martin Eichenbaum, and Sergio Rebelo (2009) and by Gauti Eggertsson (2008) that the fiscal multiplier will be larger now, with a slack economy and zero nominal interest rates. In Hall's own analysis using a simple dynamic New Keynesian model, a larger fiscal multiplier results because the Taylor rule that otherwise would raise nominal interest rates in response is inoperative: because interest rates are already constrained to be higher than the monetary authority would like them to be, raising the desired interest rate has no effect on monetary policy. But the multipliers in these cited papers rise by more than in Hall's analysis, and so one wonders whether there is more to the story.

As to other issues, I can think of reasons why nonmilitary spending could have stronger positive effects than military spending on private domestic output, but also reasons why the effects could be weaker. And consistent with what is known from the literature on fiscal consolidations (for example, Perotti 1999), I worry that the benefits of today's expansionary fiscal policies may be undercut by concerns about the 
government's commitment to keeping the policies temporary and about its willingness to confront the nation's long-term fiscal challenges. Indeed, the current recession has seen an unprecedented increase in the perceived probability of default on U.S. Treasury obligations implied by credit default swap prices (Auerbach and Gale 2009). Although this increase has subsided since early 2009 and may have had more to do with the recession and gyrations in credit markets, these prices are still elevated relative to where they were in the past.

I also wonder about some of the more specific conclusions Hall reaches when evaluating the 2009 stimulus package. In particular, he performs jujitsu on critics of the package's slow implementation of government purchases: using his simple structural model, he estimates (table 6) that a front-loaded stimulus of the same total size would have had smaller effects on GDP than the actual package. In Hall's words, "Back-loading is a desirable feature of a stimulus program." I am not sure exactly what generates this result, but I assume that it has something to do with an announced change in government spending having effects on private behavior similar to an immediate one, but without the crowding-out effect. It would have been helpful if the discussion were more explicit on this point. In particular, one would expect this result to be sensitive not only to the credibility of policy announcements, but also to the extent to which household behavior is forward looking. (Hall does devote some space to the question of how consumption constraints affect multipliers. Much of this discussion is helpful, although the analysis done using the fixed-real-wage model is less so because of that model's strange properties.)

In summary, Hall has produced an interesting and thought-provoking paper, compelling further thought about the channels through which government purchases might affect output, both in normal times and in the very abnormal present time. In the process he has exposed one of the profession's dirty little secrets: that economists really have very little idea what the multiplier is for government purchases adopted as part of a stimulus package, during a deep recession with a binding zero bound on interest rates and a serious fiscal calamity just around the corner. The aggregate empirical evidence relates to episodes quite different in nature from this one, and the available structural models consist of many reasonable components with untested assumptions filling the interstices. In a context where the only way to generate empirical evidence is through big wars and deep recessions, one is hesitant to wish for more data, but evidence, as well as careful modeling, is needed to move the state of knowledge forward. 


\section{REFERENCES FOR THE AUERBACH COMMENT}

Auerbach, Alan J., and William G. Gale. 2009. "The Economic Crisis and the Fiscal Crisis, 2009 and Beyond." Tax Notes 125, no. 1 (October 5): 101-30.

Christiano, Lawrence, Martin Eichenbaum, and Sergio Rebelo. 2009. "When Is the Government Spending Multiplier Large?” Working Paper no. 15394. Cambridge, Mass.: National Bureau of Economic Research (October).

Eggertsson, Gauti B. 2008. "Can a Tax Cut Deepen the Recession?" Federal Reserve Bank of New York (December).

Perotti, Roberto. 1999. "Fiscal Policy in Good Times and Bad." Quarterly Journal of Economics 114, no. 4 (November): 1399-1436.

Ramey, Valerie A. 2009. "Identifying Government Spending Shocks: It's All in the Timing." Working Paper no. 15464. Cambridge, Mass.: National Bureau of Economic Research.

Ramey, Valerie A., and Matthew D. Shapiro. 1998. "Costly Capital Reallocation and the Effects of Government Spending." Carnegie-Rochester Conference on Public Policy 48 (June): 145-94.

\section{COMMENT BY}

CHRISTOPHER L. HOUSE Early in 2009, the American Recovery and Reinvestment Act (ARRA) was passed largely on the grounds that it would provide necessary stimulus to the economy, which was, and still is, suffering from one of the worst recessions in the postwar period. The act's provisions are projected to cost roughly $\$ 787$ billion over the next decade. This sum is divided into three broad groups: tax cuts (largely consisting of a $\$ 400$ payroll tax credit for low- and middle-income families and an extension of the alternative minimum tax exemption) make up roughly $\$ 288$ billion; transfers to state and local governments are roughly $\$ 144$ billion; and increased federal spending accounts for roughly $\$ 355$ billion. The bulk of the funds will be spent by the end of 2013 .

Against this backdrop, many researchers have begun to reexamine whether stimulative fiscal policies like the ARRA are effective. Robert Hall's paper addresses two questions relevant to this research: First, empirically, how much does economic activity increase when the government purchases more goods and services? Second, what do existing macroeconomic models say about the likely effects of government spending on the economy, and do the models' insights match the empirical evidence? Hall casts his analysis in terms of the magnitude of the government spending multiplier: the change in real GDP caused by a temporary increase in real government purchases of one dollar.

Hall's paper reviews both empirical evidence and theory to try to get at these questions. The empirical evidence consists primarily of estimates of 
the change in GDP (and consumption) associated with a change in military spending. This strategy, which other researchers (notably Ramey and Shapiro 1998 and Ramey 2009) have also used, is based on the plausible assumption that changes in military spending are driven by geopolitical events unrelated to economic conditions. Although the evidence is far from conclusive, the magnitude of the spending multiplier for output appears to be between 0.5 and 1.0. The estimated consumption multiplier is near zero and slightly negative. Hall then studies a macroeconomic model to see whether it can provide additional insights into the magnitude of the multiplier. The model has a basic neoclassical substructure but allows for non-neoclassical features such as a high labor supply elasticity and a countercyclical markup. Hall concludes that neoclassical models necessarily produce small output multipliers and negative consumption multipliers. Larger multipliers are possible only if the markup is sufficiently countercyclical and if labor supply is sufficiently elastic.

EMPIRICAL ANALYSIS. Because Hall assumes that military purchases are exogenous to other determinants of economic activity, he uses OLS estimates to gauge the economy's reaction. For his entire sample from 1930 to 2008 , he obtains an output multiplier of roughly 0.55 with a standard error of 0.08 . The multiplier for consumption is -0.05 with a standard error of 0.03. Different subsamples produce different estimates and standard errors, but the output multiplier is always less than 1.0 and the consumption multiplier is always negative and close to zero.

Although Hall's approach is a natural one to take and, in my assessment, provides essentially the best information we have, it suffers from a severe lack of data. When one examines the time path of real government spending, the immediate sense is that there have been perhaps five or six large, sharp changes in military spending, and little else. Before the onset of World War II, annual U.S. military spending was roughly $\$ 18$ billion, or 2 percent of GDP. By 1944 military spending had increased to almost $\$ 1.2$ trillion, or 65 percent of GDP. A similarly dramatic swing occurred at the end of the war as military spending fell. The Korean War also led to large variations in government spending. Annual military spending rose from $\$ 171$ billion to $\$ 467$ billion at the start of the war. These few observations stand out from the remainder of the dataset and exert extraordinary weight on the estimates. The remaining observations consist of smaller absolute changes, which are smaller still as a percent of GDP. We are effectively left to base our estimates on perhaps five or six data points. Table 1 and figure 1 in Hall's paper reflect the importance of these data points in his estimates. 
An important consequence of the lack of data is that one cannot control for other factors that would likely influence the multiplier. One would expect that production would expand more in response to an increase in government purchases if the monetary authority accommodated the expansion in spending than if it did not. Similarly, if taxes were to rise with military spending (as they did at the beginning of the Korean War), the expansion in economic activity would likely be smaller. Finally, one would anticipate that increases in government purchases might be more stimulative during a business cycle trough than at a peak, since more idle resources would be available for production. Although controlling for these factors is surely important, it is not possible with such a limited data sample.

THEORETICAL ANALYSIS. To augment the empirical analysis, Hall examines the predictions of a model that allows for government spending shocks. He argues that unless the model has sharply countercyclical markups and highly elastic labor supply, the implied multiplier is low. He considers variations of the model that allow for hand-to-mouth behavior on the part of consumers, as well as nonadditively separable utility, and concludes that the basic result holds even under these modifications. Here I draw attention to one feature that Hall does not emphasize: the important role that investment demand can play in influencing the multiplier.

From a purely neoclassical perspective, there are good reasons to anticipate multipliers less than 1.0. Faced with an increase in government spending, the representative household in a neoclassical model has only three options: work more, consume less, or invest less. Typically the household chooses a combination of these options, and as a result, the multiplier is less than 1.0. How much less depends on the relative elasticities of each of these margins of adjustment. I argue below that under typical conditions, the most appealing margin for the representative household is the investment margin. In the absence of investment adjustment costs, the representative household can allow investment to vary substantially without experiencing sharp reductions in utility. Indeed, in an instructive limiting case, investment demand is completely crowded out and the multiplier is zero even when the markup is highly cyclical and labor is highly elastic.

To analyze the role of investment, I introduce an additional variable implied by Hall's model. Let $v_{t}$ be the shadow value of capital at date $t$. I assume that preferences are described by the simple additively separable case in equation 3 in Hall's paper. In this case the shadow value $v_{t}$ can be expressed recursively as

$$
v_{t}=\beta(1-\alpha) c_{t+1}^{-\frac{1}{\sigma}} h_{t+1}^{\alpha} k_{t+1}^{-\alpha}+\beta(1-\delta) v_{t+1},
$$


or as the discounted sum,

$$
v_{t}=\beta(1-\alpha) \sum_{j=0}^{\infty}[\beta(1-\delta)]^{j} c_{t+j+1}^{-\frac{1}{\sigma}} h_{t+j+1}^{\alpha} k_{t+j+1}^{-\alpha} .
$$

At the optimum, the marginal benefit of an additional unit of capital ( $v$ ) equals the marginal cost of acquiring it. This requires that $c_{t}^{-\frac{1}{\sigma}}=v_{t}{ }^{1}$

I make two short-run approximations. Specifically, I assume that the backward-looking variable $k_{t}$ and the forward-looking variable $v_{t}$ are approximately constant in the short run. The accuracy of these approximations requires that the fiscal stimulus be sufficiently temporary and that the capital goods be sufficiently long-lived (that is, the capital goods should have a sufficiently low depreciation rate). ${ }^{2}$ I discuss these approximations further below.

Treating the capital stock as fixed in the short run is permissible because the stock of long-lived capital goods is much larger than the flow of investment. As a result, even with dramatic variations in investment, the capital stock changes only slightly in the short run. With the capital stock fixed, the remaining endogenous variables can be expressed in terms of the equilibrium change in the shadow value of capital $v$. Let $\tilde{x}_{t}$ denote the percent deviation of a variable $x$ from its steady-state value; that is, $\tilde{x}_{t} \equiv\left(x_{t}-\bar{x}\right) / \bar{x}$. With some algebra, one can show that the percent change in output is

$$
\tilde{y}_{t}=\frac{\alpha}{\frac{1}{\psi}+(1-\alpha)\left(1-\frac{\omega \alpha}{1-\alpha}\right)} \times \tilde{v}_{t} .
$$

The expression in the denominator is the difference between the slope of the labor supply curve and the slope of the effective labor demand curve (the labor demand curve taking the change in the markup into account). As long as effective labor demand slopes downward, this term is positive. In this case output increases only if the shadow value $v$ increases. Hall focuses on conditions under which the coefficient multiplying $v$ is very large. For a given change in $v$, the higher this coefficient is, the larger the multiplier will be. Specifically, the multiplier will be high if the markup is

1. Mechanically, $v$ is the Lagrange multiplier on the capital accumulation constraint; it is not Brainard-Tobin's $q$. Instead, $q$ is the ratio of $v$ and the marginal utility of consumption.

2. The discussion here draws on the analysis in Barsky, House, and Kimball (2007) and House and Shapiro (2008). See those papers for a more detailed discussion of the approximations. See also House (2009). 
very countercyclical (high $\omega$ ), or if labor supply is very elastic (high $\psi$ ), or if labor demand is very elastic ( $\alpha$ near 1$)$. Note also that for output to increase, $v$ must increase. Since $v$ is equal to the marginal utility of consumption in equilibrium, $c$ must fall, implying a negative consumption multiplier.

How much will the shadow value $v$ fall? In most models the shadow value moves only slightly. The short-run approximation mentioned above treats $v$ as constant, so that $\tilde{v}_{t}=0$. To understand this approximation, look again at equation 2 . The fiscal stimulus will influence $v$ by causing changes in $c_{t}^{-\frac{1}{\sigma}}, h_{t}^{\alpha}$, and $k_{t}^{-\alpha}$. Because the fiscal stimulus is temporary, these changes are temporary, and most of the future terms in equation 2 remain close to their steady-state values. As a result, the difference between $v_{t}$ and its steady-state level is attributed entirely to the changes in the first few terms in the expression. Provided that the household is sufficiently patient and the depreciation rate sufficiently low, the value of capital is anchored by the future, long-run terms in the expression. Put differently, for sufficiently long-lived capital goods, transitory changes in $c_{t}^{-\frac{1}{\sigma}}, h_{t}^{\alpha}$, and $k_{t}^{-\alpha}$ have negligible influences on $v_{t}$. Naturally, the payoff from investing in a long-lived capital good is dictated by future, long-run considerations and is approximately independent of short-run events. As a result, assuming that the future is only slightly influenced by a temporary fiscal stimulus, the shadow value $v$ is approximately constant in the short run.

Using the short-run approximation $v_{t} \approx \bar{v}$, equation 3 implies that there is no change in total output, and thus the multiplier is zero. This is true regardless of the parameter values for $\psi$ and $\omega$. Of course, the approximations $v_{t} \approx \bar{v}$ and $k_{t} \approx \bar{k}$ are exactly true only for arbitrarily short-lived fiscal policies or arbitrarily low depreciation rates. For longer-lived policies like the ARRA and for realistic depreciation rates, the approximations are not exact.

To judge the accuracy of the approximations away from the lowdepreciation limit, I solve the model out exactly allowing for $v$ and $k$ to move endogenously in response to the policy. I solve the model and compute the multiplier for a variety of model specifications and depreciation rates. The parameter values used for each variation of the model are given in table $1 .^{3}$

3. I hold the investment-GDP ratio constant when I vary the depreciation rate. In addition to the parameter values in the table, $\alpha=0.65, \beta=0.98, \phi=0.70, \sigma=0.20$, the consumption-GDP ratio is 0.60 , and the ratio of government spending to GDP is 0.20 . These parameter values are held constant across all simulations. Consumption-labor complementarity modifies the labor supply condition (equation 20 in Hall's paper). In log deviations, the modified labor supply condition used in the simulations here is $\frac{1}{\psi} \tilde{h}_{t}=-\frac{1}{\sigma} \tilde{c}_{t}+\tilde{w}_{t}+\theta\left(\tilde{h}_{t}-\tilde{c}_{t}\right)$. Hand-to-mouth consumers set $\tilde{c}_{t}=\tilde{y}_{t}$; other consumers behave according to the permanent income hypothesis. 
Table 1. Parameter Values

\begin{tabular}{lcccc} 
Model & $\begin{array}{c}\text { Frisch } \\
\text { elasticity } \\
(\psi)\end{array}$ & $\begin{array}{c}\text { Markup } \\
\text { cyclicality } \\
(\omega)\end{array}$ & $\begin{array}{c}\text { Consumption-labor } \\
\text { complementarity } \\
(\theta)\end{array}$ & $\begin{array}{c}\text { Fraction of } \\
\text { hand-to-mouth } \\
\text { consumers }\end{array}$ \\
\hline Baseline & 1.00 & 0 & 0 & 0 \\
Cyclical markup & 1.00 & 0.30 & 0 & 0 \\
Hand-to-mouth consumers & 1.00 & 0 & 0 & 0.70 \\
Infinite Frisch elasticity & $\infty$ & 0 & 0 & 0 \\
$\begin{array}{l}\text { Labor-consumption } \\
\text { complementarity }\end{array}$ & 1.00 & 0 & 0.70 & 0 \\
\hline
\end{tabular}

Figure 1 reports the multipliers for the model specifications given above and for several different depreciation rates. Each line in the figure corresponds to a variation of Hall's model. For each variation I compute the multiplier for a range of depreciation rates, which are plotted on the horizontal axis. For purposes of comparison, the vertical lines in the figure indicate depreciation rates for vehicles (roughly 17 percent), general equipment (roughly 10 percent), and structures ( 2 to 3 percent). There are two things to note about the figure. First, when the model includes New Keynesian features, the value of the multiplier is higher. As Hall emphasizes, higher

Figure 1. Simulated Government Purchases Multipliers for Various Models and Depreciation Rates

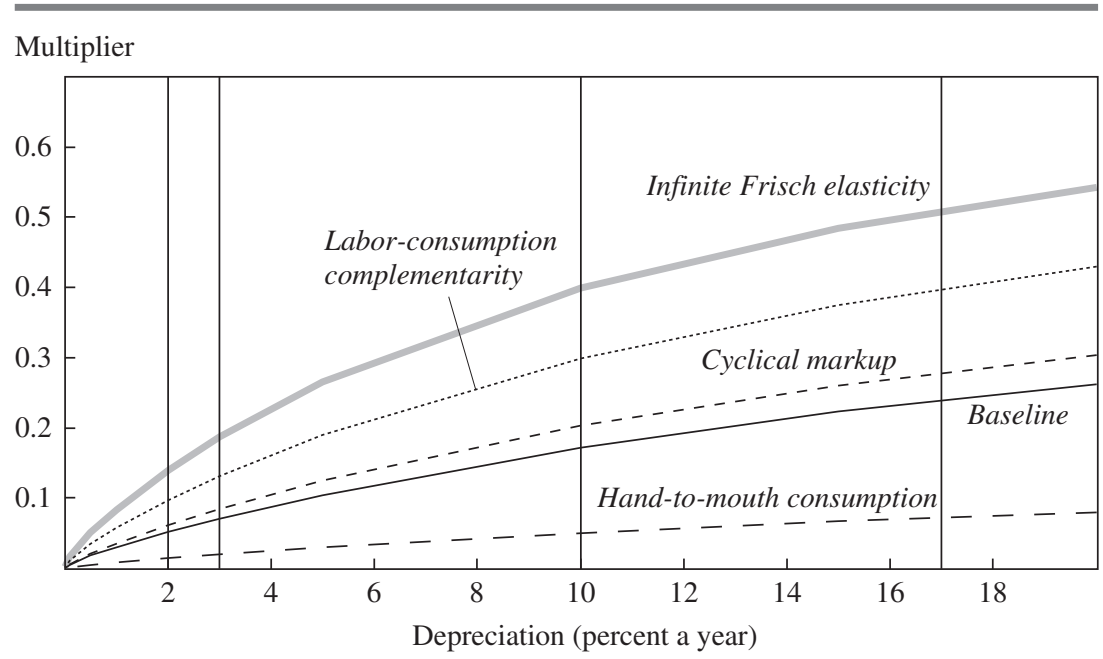

Source: Authorś calc ulations. 
labor supply elasticities and greater cyclicality of the markup result in higher output multipliers. Second, as the depreciation rate falls, the multiplier approaches zero in all of the specifications. This is a consequence of the near constancy of the shadow value $v$ for long-lived investments. As the depreciation rate falls, the shadow value becomes more anchored by the long-run terms in equation 2 and less influenced by temporary fiscal stimulus.

The reason the multiplier approaches zero as the depreciation rate falls is that the elasticity of investment demand approaches infinity. In this case the representative household does not need to reduce consumption or increase work. Instead, since the shadow value of capital is approximately unchanged, the increase in government spending can be accommodated nearly entirely by a temporary reduction in investment. That the shadow value is nearly constant is equivalent to saying that the investment demand curve is nearly flat. Of course, the fact that government spending crowds out investment is nothing new. This effect is present in the standard IS-LM model. An outward shift in the IS curve results in some crowding out, depending on the elasticity of investment. In neoclassical and New Keynesian models without adjustment costs, the IS curve is extremely elastic, and crowding out is nearly complete.

In the data, investment is indeed crowded out by government spending. Taking the estimates in table 1 in Hall's paper as given, one can calculate the implied investment multiplier. This is simply the first column of the table plus the second column minus 1 . For the entire sample the investment multiplier is roughly -0.5 . In the limiting case with low depreciation rates, neoclassical and New Keynesian models have the investment multiplier close to -1.0 , which implies that the output multiplier is close to zero.

To undo the extreme elasticity of investment demand and restore some of the traditional effects of fiscal policy, some sort of investment adjustment friction can be added to the model. Adjustment costs temper the extent to which investment is crowded out. An extreme form of adjustment cost would be one that assumes that investment is predetermined in the short run. ${ }^{4}$ To illustrate the effects of investment adjustment costs, I recalculate the multipliers under the assumption that investment cannot change, that is, that investment demand is completely inelastic.

4. Basu and Kimball (2005) consider sticky investment in a New Keynesian framework. House and Mocanu (2009) analyze investment planning costs in a model of heterogeneous firms and fixed adjustment costs. 
Figure 2. Simulated Government Purchases Multipliers with Investment Held Fixed

Multiplier

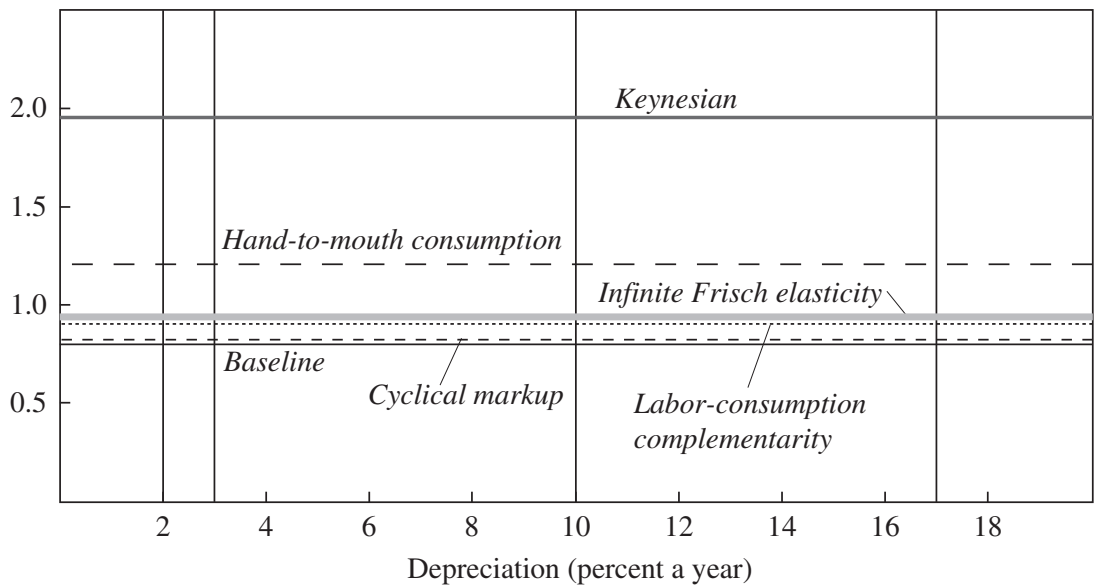

Source: Author's calculations.

Figure 2 shows the implied output multipliers for the model specifications considered previously. These are substantially larger than their counterparts in figure 1. Notice also that the multipliers do not approach zero as they did before. In fact, the depreciation rate does not influence the equilibrium at all. Since investment is assumed to be exogenous, the depreciation rate influences only the value of capital. Given investment, the remainder of the model is static. The figure also includes multipliers for a "Keynesian" specification that combines the mechanisms in the other model specifications.

Because investment typically has an extremely high elasticity of demand, the specification of investment supply often plays a crucial role in determining the magnitude of the government spending multiplier. Hall's base calibration (table 3 in his paper) is chosen so that the output multiplier is near 1.0 and the consumption multiplier is close to zero. In this case investment does not change much in equilibrium, and thus investment adjustment costs play little role in influencing the multiplier. This calibration features high labor supply elasticity, a high degree of consumption-labor complementarity, and a high cyclicality of the markup (high enough to imply an upward-sloping effective labor demand curve).

Hall provides a balanced and scholarly approach to a timely and relevant topic. Unfortunately, neither data nor theory speaks very loudly on this 
issue. Ultimately, only a limited amount of data are available on which to base conclusions, and depending on the treatment of investment, the models that are available allow for a wide range of behavior associated with temporary increases in government purchases. Whether the current stimulus measures will have the desired impact is unclear. The most one can hope for is that the consequences will become apparent once new data become available.

\section{REFERENCES FOR THE HOUSE COMMENT}

Barsky, Robert B., Christopher L. House, and Miles S. Kimball. 2007. "Sticky-Price Models and Durable Goods." American Economic Review 97, no. 3: 984-98.

Basu, Susanto, and Miles Kimball. 2005. "Investment Planning Costs and the Effects of Fiscal and Monetary Policy." Working paper. Boston College and University of Michigan.

House, Christopher L. 2009. "Fixed Costs and Long-Lived Investments." Working Paper no. 14402. Cambridge, Mass.: National Bureau of Economic Research.

House, Christopher L., and Matthew D. Shapiro. 2008. "Temporary Investment Tax Incentives: Theory with Evidence from Bonus Depreciation." American Economic Review 98, no, 3: 737-68.

House, Christopher, and Ana-Maria Mocanu. 2009. "The Timing of Investments in Fixed-Cost Models: Theory, Evidence and Implications." Working paper. University of Michigan.

Ramey, Valerie. 2009. "Identifying Government Spending Shocks: It's All in the Timing." Working Paper no. 15464. Cambridge, Mass.: National Bureau of Economic Research.

Ramey, Valerie A., and Matthew D. Shapiro. 1998. "Costly Capital Reallocation and the Effects of Government Spending." Carnegie-Rochester Conference Series on Public Policy 48: 145-94.

GENERAL DISCUSSION David Romer described two alternative views of reduced-form estimates of the government purchases multiplier: one is that it is impossible to know anything, because the data come from such few and unusual episodes, and the other is that the direction of the bias is known. Given that most of the variation in the data comes from World War II, and given all the other factors that were clearly biasing the multiplier downward at that time, 0.5 can be taken rather confidently to be the lower bound.

Bradford DeLong argued that the New Keynesian model is built on foundations of sand. The only intelligent way to view it is as an attempted exercise in mental consistency, a way to try to organize certain beliefs while leaving aside the reasons for those beliefs. Most of the time the fiscal multiplier is taken to be very low because the labor supply elasticity is low 
and markups are not strongly countercyclical, and almost all of the rest of the time the fiscal multiplier is very low because the Federal Reserve has a strong view about what nominal spending will be and acts to offset whatever fiscal policy initiatives Congress attempts. DeLong argued that there are times-namely, when the federal funds rate is essentially zero, and the effects of standard open-market operations on relative prices are unclear because cash and Treasury securities look like nearly perfect substituteswhen a combination of quantitative easing and banking recapitalization on the demand side of the credit channel, and of government asset purchases and guaranty policies on the supply side, together with fiscal expansion, have a role to play that they normally do not. It is hard, however, to justify any particular numbers that attempt to answer how much each of these supplements to normal monetary policy tools should be contributing.

Robert Gordon addressed the problem of having to rely on data from World War II and the Korean War, which were not only long ago but also atypical because supply constraints were in effect. The problem could be alleviated, he argued, by using newly available data on the buildup to World War II. These data show that between the second quarter of 1940 and the fourth quarter of 1941, the ratio of government spending to potential output rose from 12 percent to 25 percent; this period thus offers a controlled natural experiment in the size of the government spending multiplier. The annual growth rate of real GDP during this period was among the fastest in recorded history, at roughly 18 percent. The ratio of actual to potential GDP rose by 16 percentage points; increased government spending accounted for about 9 percentage points out of that increase, leaving quite a bit unexplained. Consumption and investment both rose by approximately the same amount, underlining the point that the model needs to include investment as well as consumption. These numbers suggest that the multiplier for that five-quarter period was about 1.75 , of which about 1.0 came from the government, 0.4 from consumption, and 0.4 from investment.

Michael Woodford suggested that as he understood the logic of the results derived from the standard New Keynesian model, the size of the government expenditure multiplier depends on whether real interest rates go up, and by how much, in response to the increase in government purchases. In a classical model with market clearing and price equal to marginal cost, real interest rates must rise in response to an increase in government purchases. This results in a crowding out of private spending, and thus a multiplier of less than 1, and monetary policy cannot affect real interest rates. The difference in the New Keynesian model is that monetary policy can affect 
the real interest rate. The size of the multiplier thus depends on what is assumed about monetary policy. If monetary policy is thought to increase real interest rates in response to an output increase, the multiplier will be small, but if monetary policy accommodates a fiscal expansion and keeps real interest rates from rising, the multiplier could be 1 or higher. Woodford also emphasized that the zero lower bound literature implies the importance of distinguishing between periods when the nominal interest rate is at the zero lower bound and periods when it is not. The theoretical models imply much bigger multipliers at the zero bound than in normal circumstances when monetary policy is described by something like a Taylor rule. If, in the regression sample, something more like the Taylor rule typically applied, empirical estimates should very much underestimate the multiplier that would be relevant under present circumstances, when the federal funds rate is at the zero lower bound.

Deborah Lucas noted that great emphasis has been placed on the role of the Federal Reserve in changing expectations about the duration and severity of a downturn, but generally the models do not build that in. She wondered why that role is not more central to the analysis of how the effects of government expenditure are treated.

John Williams pointed out the importance of the accelerator and of financial constraints on investment. In an environment with lots of slack, a zero interest rate, and financial constraints, the effects of fiscal policy on investment may be different than otherwise. He also said it would be interesting to see more foreign evidence on countercyclical government spending at the zero bound, in particular from Japan.

Christopher Carroll proposed that another way to work with the available data would be to look not only at episodes in foreign countries, but also at geographical variation within the United States. Not nearly enough work has been done, for example, on whether one can measure the effects on a metropolitan area of a new highway being approved for construction. This approach could also help resolve the difficult issue of teasing apart the effects of monetary policy and fiscal policy when both are active at the same time. Monetary policy applies uniformly across the entire country, whereas state and local government spending affects mainly the state or locality. Asking what "the" government spending multiplier is, he argued, is like asking what "the" temperature is. Both vary over time and space. The really interesting intellectual questions involve the extent to which the whole set of other important factors causes the multiplier to vary.

William Brainard suggested that the paper discuss the implications of the production function having a lower short-run than long-run elasticity 
of substitution between capital and labor. He noted that a putty-clay model has quite different implications than does the Cobb-Douglas function as calibrated to long-run factor shares for cyclical fluctuations in productivity and in the factor shares themselves. With a putty-clay model, a significant fraction of what are frequently labeled productivity "shocks" driving output are simply movements along the short-run production function and cyclical movements in factor shares. Although Brainard was skeptical of the importance of firms' expectations of the future price level for their output and employment decisions, he believed that expectations about the timing and strength of recovery are important to decisions about whether to lay off workers during a downturn and whether to add labor as demand picks up.

Richard Cooper noted three serious omissions from the paper's model as it applies to the current situation. First, it has no financial sector. When nominal incomes increase, it means fewer foreclosures, so mortgages continue to be paid, and directly and indirectly, through changes in markups, commercial mortgages get paid. What happens to these mortgage payments? Does the financial sector recycle them in new loans, or does it simply absorb them so as to improve capital ratios? Either way, how does the Federal Reserve respond? Second, the model assumes a closed economy. Yet imports are a substantial component of both consumer and nonconsumer expenditure. The United States is big enough that its stimulus policies should generate noticeable feedback effects from the rest of the world. Third, and conversely, because there is no "rest of the world" in the model, there is no effect on the United States from stimulus programs elsewhere. In fact, all the major countries of the world have stimulus packages in place, which should stimulate imports from the United States. A realistic model would therefore have an export component. Cooper further observed that investment as measured in the national accounts is too broad a category to be very useful. It includes what might be called "loosely productive" investment, such as investment in housing. Growth of one type of investment will have very different implications for the productive capacity of the economy than growth in another, and it is worth noting that the most interest-sensitive component of investment is housing investment.

Ricardo Reis observed that the New Keynesian model is a very large umbrella that incorporates a lot of things, but at the most fundamental level it is about retaining the neoclassical model while allowing for nominal rigidities and for an effective monetary policy. The foundations of the model are solid, he argued, and as much work has been done on the foundations of nominal rigidities as on the foundations of an aggregate production 
function, for instance. When those foundations are described as being shaky, what is usually meant is that the details or the implementation of the model are shaky. It is the particular model of nominal rigidities that may be shaky, not the presence of some form of nominal rigidities.

Vincent Reinhart underlined the point that the fiscal multiplier is likely to be largest when monetary policy is pinned to the zero bound. That raises an issue about the applicability of data from two big war buildups in estimating the fiscal multiplier, especially because at that time the Federal Reserve was constrained not by a lower but by an upper bound on interest rates. The Treasury Support Program put a ceiling on interest rates at various points on the yield curve, and there was automatic accommodation of policy. Reinhart wondered whether one should expect multipliers closer to that experience, given that policy is similarly constrained today.

Janice Eberly raised the issue of investment adjustment costs and capital adjustment costs. She thought that putting investment adjustment costs in the model, or making investment a state variable, probably would have dramatic effects. Some work along these lines has been done by Lawrence Christiano, Martin Eichenbaum, and Charles Evans, whose model works well in a monetary setting trying to replicate impulse response functions, but does not perform as well with firm-level data. A gap emerges between matching firm-level moments and matching aggregate moments, which suggests that before putting investment adjustment costs into the aggregate model, the source of the smoothness in the aggregate data needs to be fleshed out. Simply including investment adjustment costs is too ad hoc. Especially in the current situation, parameters from normal times should not be imposed on the investment data.

David Laibson suggested a micro foundation for the Keynesian consumption function, namely, hyperbolic discounting. Agents end up putting all their wealth into illiquid assets, and thus their consumption becomes highly responsive to changes in their high-frequency labor income. Laibson also expressed interest in seeing a welfare analysis corresponding to the simulations showing what the implicit shadow value of government expenditure is and how these different experiments translate into welfare consequences.

Linda Goldberg seconded Cooper's observation that the paper's model is a closed economy model, and she suggested fleshing it out with some international influences. U.S. auto imports experienced a big uptick in July, which suggests that some of the stimulus from the "Cash for Clunkers" program was felt outside of the United States. International considerations 
are also relevant to the financing of government expenditure; if it is financed abroad, an important question is how elastic the available savings are. That elasticity could have a strong impact on whether there is an interest rate response, how large it is, and how much investment might be crowded out. Goldberg also mentioned some recent work by Giancarlo Corsetti and others on the dynamics of this financing in an open-economy model, which finds that a key part of the adjustment mechanism depends on the assumptions made about exchange rate adjustment. 
